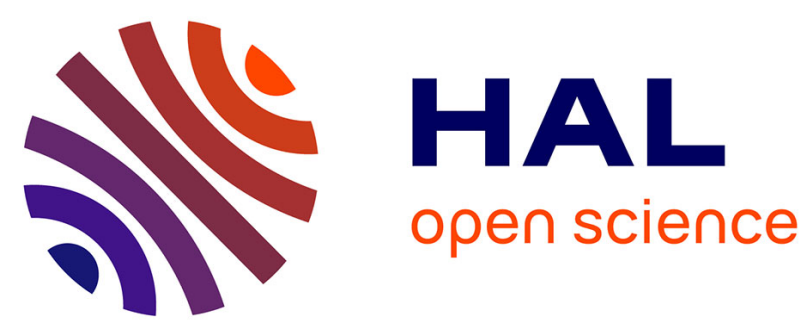

\title{
Enhanced bioaccumulation of mercury in deep-sea fauna from the Bay of Biscay (north-east Atlantic) in relation to trophic positions identified by analysis of carbon and nitrogen stable isotopes
}

Tiphaine Chouvelon, Jérôme Spitz, Florence Caurant, Paula

Mèndez-Fernandez, Julien Autier, Aurélie Lassus-Débat, Alexis Chappuis, Paco Bustamante

\section{- To cite this version:}

Tiphaine Chouvelon, Jérôme Spitz, Florence Caurant, Paula Mèndez-Fernandez, Julien Autier, et al.. Enhanced bioaccumulation of mercury in deep-sea fauna from the Bay of Biscay (north-east Atlantic) in relation to trophic positions identified by analysis of carbon and nitrogen stable isotopes. Deep Sea Research Part I: Oceanographic Research Papers, 2012, 65, pp.113-124. 10.1016/j.dsr.2012.02.010 . hal-00694521

\section{HAL Id: hal-00694521 \\ https://hal.science/hal-00694521}

Submitted on 4 May 2012

HAL is a multi-disciplinary open access archive for the deposit and dissemination of scientific research documents, whether they are published or not. The documents may come from teaching and research institutions in France or abroad, or from public or private research centers.
L'archive ouverte pluridisciplinaire HAL, est destinée au dépôt et à la diffusion de documents scientifiques de niveau recherche, publiés ou non, émanant des établissements d'enseignement et de recherche français ou étrangers, des laboratoires publics ou privés. 
Enhanced bioaccumulation of mercury in deep-sea fauna from the Bay of Biscay (northeast Atlantic) in relation to trophic positions identified by analysis of carbon and nitrogen stable isotopes

Chouvelon T., Spitz J., Caurant F., Mèndez-Fernandez P., Autier J., Lassus-Débat A. , Chappuis A, Bustamante P.*

Littoral Environnement et Sociétés, UMR 7266 CNRS - Université La Rochelle, 2 rue Olympe de Gouges, F-17042 La Rochelle Cedex 01, France

Corresponding author: Pr. Paco Bustamante

Littoral Environnement et Sociétés

UMR 6250 -Université de La Rochelle

2 rue Olympe de Gouges

F-17042 La Rochelle (France)

Tel.: (+33) 546507625

Fax: (+33) 546456284

E-mail:pbustama@univ-lr.fr

*Corresponding author. Tel.:+33 546507 625; e-mail: pbustama@univ-lr.fr 
Abstract: The Bay of Biscay (north-east Atlantic) is an open marine ecosystem of particular concern in current European environmental policies. Indeed, it supports both a high biological diversity and numerous anthropogenic activities such as important fisheries. For the first time, stable isotope analyses (SIA) of carbon and nitrogen and analysis of total mercury ( $\mathrm{T}-\mathrm{Hg}$ ) concentrations in the muscle (edible flesh) were performed on adult stages of a wide range of species (i.e., 120 species) from various taxa and various habitats of this ecosystem. Concentrations of this non-essential metal, toxic to all living organisms, ranged from 39 to 5074 ng.g ${ }^{-1}$ dry weight. Calculations of species' trophic positions (TPs) through SIA revealed a limited effect of TP in explaining $\mathrm{Hg}$ bioaccumulation by high trophic level consumers in particular. On the contrary, our results suggest an important role of habitat and/or feeding zone, which strongly influence muscle $\mathrm{Hg}$ bioaccumulation. Deep-sea fish species effectively presented the highest $\mathrm{Hg}$ concentrations. Possible interactions between biological factors (e.g., age of deep-sea organisms) and bioavailability of the metal in the deep-sea environment are discussed to explain such enhanced bioaccumulation of $\mathrm{Hg}$ by deep-sea fauna in the Bay of Biscay. This study also highlights a potential risk for human health when deep-sea fish are consumed frequently.

Keywords: Metal, stable isotope, trophic transfer, fish, mollusc, crustaceans, marine environment.

\section{Highlights:}

- One hundred and twenty marine species were analysed for carbon and nitrogen stable isotopes and muscular mercury concentrations.- Trophic position poorly influenced muscle Hg bioaccumulation compared to the feeding zone or habitat. - Deep-sea organisms presented the highest $\mathrm{Hg}$ concentrations. 


\section{Introduction}

Maintaining both a sustainable exploitation of natural marine resources and the integrity (i.e., structure and functioning) of marine ecosystems is a challenge that human societies currently face and that they should meet through ecosystem-based management (Larkin, 1996, Curtin and Prellezo, 2010). To implement ecosystem-based management for European marine ecosystems, the European Commission recently adopted the Marine Strategy Framework Directive (MSFD). The MSFD proposes the use of 11 qualitative descriptors to define and to monitor the "good environmental status" of ecosystems of concern, by the year 2020 at the latest, among which are the descriptors "food webs", "contaminants", and "contaminants in fish and seafood for human consumption" (European Commission, 2008, 2010).

Trophic linkages between organisms of a food web effectively take a central place in the general structure and functioning of marine ecosystems (Cury et al., 2003). In the last decades, stable isotope analyses (SIA) of carbon (C) and nitrogen (N) in consumers' tissues $\left(\delta^{13} \mathrm{C}, \delta^{15} \mathrm{~N}\right)$ have proved to be a powerful tool to describe the trophic ecology and trophic relationships within marine organisms at the ecosystem scale. This method represents an alternative or complementary tool to the traditional methods of dietary studies (e.g., analysis of guts or stomach contents) (Michener and Kaufman, 2007). Indeed, the use of these ecological tracers is principally based on the fact that 1) primary producers of an ecosystem generally present different isotopic compositions, due to the different nutrients fixed and the biochemical cycle they use for photosynthesis (Peterson and Fry, 1987; France, 1995); 2) the enrichment in ${ }^{13} \mathrm{C}$ and ${ }^{15} \mathrm{~N}$ between a source and its consumer (also called Trophic Enrichment Factor, TEF) is relatively predictable. This enrichment is less important in $\mathrm{C}(\leq 1 \%$ o $)$ than in $\mathrm{N}$ (3.4\%o on average) (De Niro and Epstein 1978, 1981; Post, 2002a). Hence, $\delta^{13} \mathrm{C}$ values are 
generally used as a tracer of the habitat or the feeding zone of organisms (Hobson, 1999; France, 1995). $\delta^{15} \mathrm{~N}$ values are mainly used as an indicator of the trophic position (TP) of organisms and have been widely used to calculate the absolute trophic level of organisms in various ecosystems (Hobson and Welch, 1992; Lesage et al., 2001; Le Loc'h et al., 2008). Furthermore, the knowledge of marine food webs' structure, through food-chain length for example (Post, 2002b; Vander Zander and Fetzer, 2007), is one key aspect for understanding the transfer of certain contaminants such as mercury (Hg) in those food webs (Wang, 2002). Overall, SIA and derived TP and/or feeding zones of organisms may thus help to investigate the transfer of $\mathrm{Hg}$ in food webs of interest (e.g., Vander Zanden and Rasmussen, 1996; Lavoie et al., 2010).

$\mathrm{Hg}$ is a metal released in the environment from both natural and anthropogenic sources (e.g., volcanism and waste incineration), reaching the ocean through river inputs and atmospheric depositions (Fitzgerald et al., 2007). Trophic transfer is then the main pathway for the intake of $\mathrm{Hg}$ by organisms; furthermore, this metal is particularly known to bioaccumulate in higher trophic level consumers (Eisler, 1987; Cossa et al., 1990) and to biomagnify along food chains (Gray, 2002). However, among metals, $\mathrm{Hg}$ has no known biological function (i.e., it is a non-essential element) and is toxic to all living organisms including human consumers (Eisler, 1987; Boening, 2000).

The biomagnification of $\mathrm{Hg}$ lies in the fact that microorganisms methylate $\mathrm{Hg}$ in marine sediments from the shelf (Bacci, 1989; Fitzgerald et al., 2007). The production of methyl-Hg may also be enhanced in sub-thermocline low oxygen waters, in which the organic form dimethyl- $\mathrm{Hg}$ becomes the dominant form among the organic forms of $\mathrm{Hg}$ in the environment (Mason et al., 1995). However, dimethyl-Hg is a very unstable form and the principal source of monomethyl-Hg. This last organic form of $\mathrm{Hg}$ is finally the most stable form, the most 
bioavailable and thus the more bioaccumulated by marine organisms (Fitzgerald et al., 2007). It is also the most toxic form of $\mathrm{Hg}$ (Boening, 2000). Therefore, some authors have already suggested an enhanced bioaccumulation of $\mathrm{Hg}$ in biota from mesopelagic and deep-water environments (Monteiro et al., 1996; Thompson et al., 1998; Choy et al., 2009). Indeed, seabirds feeding on mesopelagic fish exhibit higher $\mathrm{Hg}$ concentrations in their feathers than epipelagic feeders (Thompson et al., 1998; Ochoa-Acuña et al., 2002).

The Bay of Biscay is a marine environment of particular concern in current European environmental policies. It is a large bay opened on the North-East Atlantic Ocean, located from 1 to $10^{\circ} \mathrm{W}$ and from 43 to $48^{\circ} \mathrm{N}$ (Fig. 1). Along the French coast, the continental shelf covers over $220000 \mathrm{~km} 2$ and extends more than $200 \mathrm{~km}$ offshore in the north of the Bay and only $10 \mathrm{~km}$ in the south. Two main river plumes (i.e., the Loire and the Gironde) influence its hydrological structure (Planque et al., 2004; Puillat et al. 2004). The Bay of Biscay also presents a vast oceanic domain and a continental slope indented by numerous canyons (Koutsikopoulos and Le Cann, 1996). Overall, the Bay of Biscay supports a rich fauna and is subjected to numerous anthropogenic activities such as important fisheries (Lorance et al., 2009). Nonetheless, in its last report, the OSPAR commission particularly underlined the general lack of supervision in the deep waters of the Bay of Biscay (i.e., below $200 \mathrm{~m}$ depth and thus beyond the shelf-edge). Moreover, very few studies have investigated the level of contamination of fish and seafood from the Bay of Biscay (OSPAR, 2010; Borja et al., 2011), and these studies have mainly focused on few, coastal and/or mollusc species in the case of Hg (e.g., Cossa et al., 1990 and references therein; Claisse et al., 2001; Bustamante et al., 2006).

In this context, the specific objectives of this study were 1) to calculate the TP of a wide variety of organisms from the different food webs of the Bay of Biscay through SIA; 2) to 
evaluate the transfer and/or the behaviour of $\mathrm{Hg}$ in those food webs, with the hypothesis that oceanic and/or deep-sea organisms may be more contaminated than neritic organisms due to a greater exposure to bioavailable $\mathrm{Hg}$ (i.e., monomethyl-Hg), as suggested by some authors in other areas (Monteiro et al., 1996; Thompson et al., 1998; Choy et al., 2009).

\section{Materials and methods}

\subsection{Sampling}

In this study, more than 1000 individuals belonging to 120 species were sampled. Those species covered a wide range of representative taxa of the different Bay of Biscay food web components, including both cartilaginous and bony fish, molluscs, and crustaceans (Table 1). All organisms were collected during the EVHOE (EValuation des ressources Halieutiques de l'Ouest de l'Europe) groundfish surveys conducted by the Institut Français de Recherche pour l'Exploitation de la Mer (IFREMER), from the continental shelf to the shelf-edge of the French part of the Bay of Biscay in the autumns of 2001 to 2010. During these surveys, bottom and pelagic trawls were also performed in the canyons indenting the continental slope to specifically collect oceanic and deep-sea organisms.

As many species switch their diet during the ontogenesis with increasing size (Karpouzi and Stergiou, 2003; Chouvelon et al., 2011), the different species have to be compared at equivalent stages of their life histories (Jennings et al., 2001). Moreover, the age of individuals is one of the most influential factors in $\mathrm{Hg}$ bioaccumulation in the muscle of marine organisms (e.g., Monteiro and Lopes, 1990; Rossi et al., 1993; Cronin et al., 1998). Thus, only adult individuals and only a relatively narrow range of sizes within each species 
were sampled among most of the species analysed (Chouvelon et al., 2011). When several size classes were available for a species, they were treated separately (see Table 1).

Each individual was measured and a piece of muscle was taken for SIA and $\mathrm{Hg}$ analyses. Indeed, muscle is the reference tissue in food web studies inferred from SIA (Hobson and Welch, 1992; Pinnegar and Polunin, 1999). It allows comparisons of isotopic signatures between individuals and taxa, minimizing inter-tissue differences in terms of biochemical and physiological properties like protein turnover rate and metabolic routing (Cherel et al., 2005). Concerning $\mathrm{Hg}$, this metal likely binds with sulphydryl groups of muscular proteins in the muscle (Bloom, 1992; Bustamante et al., 2006). Hg concentrations in the muscle were thus thought to reflect metal exposure in the relatively long term, in comparison with other soft tissues such as the liver of fish, or the digestive gland of cephalopods (Reinfelder et al., 1998; Lacoue-Labarthe et al., 2009). After collection, muscle samples were immediately placed in individual plastic bags, frozen at $-20^{\circ} \mathrm{C}$ and freeze-dried. Freeze-dried tissues were finally ground into a fine powder and stored in individual plastic vials until further analyses.

\subsection{Samples preparation, SIA and Hg analyses}

For SIA, lipids were extracted from muscle subsamples using cyclohexane, as described by Chouvelon et al. (2011), because they are highly depleted in ${ }^{13} \mathrm{C}$ relative to other tissue components (De Niro and Epstein, 1977). Then, $0.40 \pm 0.05 \mathrm{mg}$ subsamples of lipid-free powder were weighed in tin cups for SIA. SIA were performed with a Thermo Scientific Flash EA1112 elemental analyser coupled to a Thermo Scientific Delta V Advantage mass spectrometer (CF IR-MS). The results presented in this study are given in the usual $\delta$ notation relative to the deviation from standards (Pee Dee Belemnite for $\delta^{13} \mathrm{C}$ and atmospheric 
nitrogen for $\left.\delta^{15} \mathrm{~N}\right)$ in parts per thousand (\%o). Based on replicate measurements of internal laboratory standards, the experimental precision is \pm 0.15 and $\pm 0.20 \%$ o for $\delta^{13} \mathrm{C}$ and $\delta^{15} \mathrm{~N}$, respectively. However, most of the isotopic results are not detailed here but in Chouvelon et al. (in press). Indeed, as one of the specific objectives of this study was to calculate TP from SIA, only values of stable isotopes-derived TPs are presented for all species (see calculation below).

Total Hg analyses were carried out with an Advanced Mercury Analyser (ALTEC AMA 254) on at least two homogenized dry muscle tissue subsamples (untreated powder) for each individual. For $\mathrm{Hg}$ determination, the metal was evaporated by progressive heating up to $800^{\circ} \mathrm{C}$, then held under an oxygen atmosphere for $3 \mathrm{~min}$, and finally amalgamated on a gold net. Afterwards, the net was heated to liberate the collected $\mathrm{Hg}$, which was finally measured by atomic absorption spectrophotometry. $\mathrm{Hg}$ analyses were run according to a thorough quality control programme including the analysis of a certified reference material (CRM) TORT-2 (lobster hepatopancreas; National Research Council, Canada). CRM aliquots were treated and analysed in the same conditions as the samples. CRM results were in good agreement with the certified values, with an average recovery rate of $95 \%$. The detection limit was $5 \mathrm{ng} . \mathrm{g}^{-1}$ dry weight (dwt). All Hg concentrations in tissues reported below are expressed in ng. $g^{-1}$ dwt.

\subsection{Data treatment}

\subsubsection{Definition of species' general distribution}

The spatial distribution (that we assume to generally correspond to the habitat and/or the feeding zone) of each species analysed was defined on both the "horizontal" (i.e., from coastal 
to oceanic or deep sea areas) and "vertical" axes (i.e., distribution in the water column or benthic $v s$. benthopelagic $v s$. pelagic). On the horizontal axis of the distribution, species were classified according to the depth layer in which they were sampled. This depth layer corresponds to the average depth under the research vessel at the end of trawling for individuals of a species: $<30 \mathrm{~m}$; from 31 to $120 \mathrm{~m}$ depth; $121-200 \mathrm{~m} ; 201-600 \mathrm{~m}$; $\geq 600 \mathrm{~m}$ (Fig. 1). On the vertical axis of distribution (i.e., distribution in the water column), species were first classified following general published literature for most species (Quéro, 2003; Palomares and Pauly, 2010). Finally, species' general distribution was refined following specific shipboard surveys data in the area for fish species in particular (Lorance et al., 2000; Trenkel et al., 2009) (Table 1).

\subsubsection{Calculation of species' trophic positions from SIA}

A previous study in the area highlighted the importance of considering spatial variations in stable isotopic signatures to calculate the TPs of organisms from SIA (Chouvelon et al., in press). Indeed, this study revealed that $\delta^{13} \mathrm{C}$ and $\delta^{15} \mathrm{~N}$ values decreased significantly from inshore to offshore species. Thus, the authors recommended considering several baselines when deriving trophic positions from $\delta^{15} \mathrm{~N}$ values at the scale of such an open marine ecosystem with a priori several (but probably linked) food webs.

In the present study, we first continued the investigation of the inshore-offshore gradient of isotopic signatures at the species and individual scales. To this end, three species that belong to three different trophic guilds and with individuals sampled in the different habitats along the inshore-offshore gradient (i.e., from coastal to oceanic waters) were selected: the scallop Pecten maximus (a suspended particulate organic matter (POM) feeder), the gastropod 
Scaphander lignarius (a sub-surface deposit feeder), and the European anchovy Engraulis encrasicolus (a small pelagic fish, zooplankton feeder).

Then, taking into account such spatial variations in isotopic signatures, we calculated the TPs of each organism analysed in this study. The formula generally used to calculate such trophic positions through SIA is as follows (Post, 2002a):

$\mathrm{TP}_{\text {consumer }}=\mathrm{TP}_{\text {basis }}+\left(\delta^{15} \mathrm{~N}_{\text {consumer }}-\delta^{15} \mathrm{~N}_{\text {basis }}\right) / \mathrm{TEF}$

where:

- $\mathrm{TP}_{\text {basis }}$ is the trophic position of the primary consumer used to estimate the TPs of other consumers in the food web. In our study, we estimated that the suspended POM feeder $P$. maximus was the most relevant species to directly reflect the whole organic matter at the base of food webs in the Bay of Biscay, the POM being a mix of primary production (i.e., phytoplankton and/or phytobenthos in coastal areas) and other detritical or regenerated material;

- $\delta^{15} \mathrm{~N}_{\text {consumer }}$ is the value measured in the consumer whose TP we aim to calculate;

$-\delta^{15} \mathrm{~N}_{\text {basis }}$ should be the average value of the primary consumer used (i.e., P. maximus in this case). Due to evidence of an inshore-offshore gradient of isotopic signatures in the Bay of Biscay (Chouvelon et al., in press), and particularly within individuals of P. maximus in this study (see below), $\delta^{15} \mathrm{~N}_{\text {basis }}$ in the formula above has been corrected: firstly as a function of the parameters of the regression line obtained for P. maximus (Fig. 2), and secondly as a function of the $\delta^{13} \mathrm{C}$ value of the consumer $\lambda$ considered, that is:

$\delta^{15} \mathrm{~N}_{\text {basis }}=\mathrm{Y}=1,556 * \delta^{13} \mathrm{C}_{\text {consumer }}+33,47$

- TEF is the Trophic Enrichment Factor for the $\delta^{15} \mathrm{~N}$ difference between a source and its consumer. In general, when considering whole ecosystems, the average $3.4 \%$ is used as the 
TEF (Post, 2002a). Nevertheless, there is increasing evidence in the literature that the TEF may be highly variable as a function of the consumer's taxa, or as a function of the type and the quality of the consumer's food (Vanderklift and Ponsard, 2003; Caut et al., 2009). Given the wide variety of consumers sampled in the Bay of Biscay, we thus used a TEF appropriate to each major type of consumer analysed in this study, following the taxonomic criteria in particular, and derived from literature (Table 2).

\subsubsection{Generalized Additive Modelling (GAM) for muscle Hg concentrations}

Gaussian Generalized Additive Models (GAMs) were fitted to average log-transformed $\mathrm{Hg}$ concentrations for each species analysed for metal concentrations in the muscle (i.e., $\mathrm{n}=120$ ), using the mgcv package in $\mathrm{R}$ (R Development Core Team, 2010). In this way, GAMs were used to identify TP-related, spatial and taxonomic trends in explaining variability in $\mathrm{Hg}$ concentrations (Zuur et al., 2007). The average TP of species was considered as a continuous explanatory variable, while the depth layer of sampling of species, the distribution of species in the water column (i.e., benthic, benthopelagic or pelagic), and the taxa (i.e., Actinopterygian fish, Chondrichthyan fish, crustaceans, or molluscs) were treated as categorical explanatory variables in the model. The general form of the model performed on the 120 species analysed for muscle $\mathrm{Hg}$ concentrations was thus:

$\log [\mathrm{Hg}]=\mathrm{s}(\mathrm{TP})+$ Depth layer of sampling + Water column distribution + Taxa.

The assumption of Gaussian error distributions was finally checked through the residuals of the model (homogeneity, normality, and no obvious pattern in residuals in general). 


\section{Results}

\subsection{Trophic positions of food webs' components}

First, within each of the three species analysed for spatial variations in stable isotopic signatures on the horizontal axis (i.e., P. maximus, S. lignarius, and E. encrasicolus), the inshore-offshore gradient was confirmed. $\delta^{13} \mathrm{C}$ and $\delta^{15} \mathrm{~N}$ values decreased from individuals trawled inshore to individuals trawled offshore (Fig. 2). Moreover, the slopes of the regressions were very close for the three species (i.e., varying from 1.556 in P. maximus to 1.631 in S. lignarius and finally 1.740 in E. encrasicolus; Fig. 2).

TP derived from this variable isotopic baseline along the inshore-offshore gradient varied greatly among species and taxa from the Bay of Biscay's food webs analyzed. Individuals of the great scallop P. maximus trawled on the shelf edge displayed the lower TP (1.9), whereas the highest TP (5.0) was found in the marbled electric ray Torpedo marmorata. Considering taxa, TP ranged from 2.0 on average in bivalve molluscs to 4.2 on average in Chondrichthyan fish, reaching an average of 2.4 in gastropod molluscs, 3.7 in cephalopod molluscs, 3.1 in crustaceans, and finally 4.0 in Actinopterygian fish (Table 1).

Fish taxa (both Actinopterygians and Chondrichthyans) displayed a higher proportion of high TP consumers (i.e., > 4.0) than did crustaceans and molluscs taxa (Fig. 3). Considering the different environments where species were trawled (i.e., from the neritic area to the oceanic and deep-sea areas following the depth layer of sampling, or from the benthic domain to the pelagic domain following the distribution in the water column), high TP consumers were found everywhere (Fig. 3). Nevertheless, a high proportion of organisms sampled beyond 200 m depth were high TP consumers (i.e., more than 45 and $50 \%$ of consumers with TP $>4.0$ in depth layers 200-599 $\mathrm{m}$ and $\geq 600 \mathrm{~m}$, respectively) (Fig. 3). Organisms classified as benthopelagic organisms were also mostly high TP consumers also (Fig. 3). 


\subsection{Mercury concentrations and trophic positions}

Mercury concentrations varied considerably among species and taxa analyzed, ranging from $39 \mathrm{ng} \cdot \mathrm{g}^{-1} \mathrm{dwt}$ on average in the queen scallop Aequipecten opercularis to $5074 \mathrm{ng} \cdot \mathrm{g}^{-1} \mathrm{dwt}$ on average in the lantern shark Etmopterus spinax. In general, species from categories presenting a higher proportion of high $\mathrm{TP}$ consumers presented the highest $\mathrm{Hg}$ concentrations (i.e., species from the depth layers $200-599 \mathrm{~m}$ and $\geq 600 \mathrm{~m}$, benthopelagic species for the vertical distribution, and fish species among taxa analysed, as mentioned above) (Tables 1 and 3, Fig. 3). However, in the final GAM for $\mathrm{Hg}$ concentrations (deviance explained = $52.4 \%, \mathrm{AIC}=113.3)$, the effect of $\mathrm{TP}$ was not significant $(\mathrm{F}=2.01, \mathrm{p}=0.080)$. In fact, there is a trend of increasing $\mathrm{Hg}$ concentrations with increasing $\mathrm{TP}$ up to around $\mathrm{TP}=4.3$ (Fig. 4) and then the $95 \%$ confidence interval of the smoother is wide.

\subsection{Mercury concentrations and species' distribution or taxa}

Contrary to TP, the three categorical explanatory variables included in the final GAM for $\mathrm{Hg}$ concentrations (i.e., depth layer of sampling, distribution in the water column and taxa) all had a significant effect. The water column distribution was the factor that made the highest contribution to explaining the variability in muscle $\mathrm{Hg}$ concentrations $(\mathrm{F}=11.90, \mathrm{p}<0.0001)$, followed by depth layer $(\mathrm{F}=4.55, \mathrm{p}=0.002)$ and finally taxa $(\mathrm{F}=4.64, \mathrm{p}=0.004)$. Considering the distribution of organisms in the water column, pelagic species displayed significantly lower $\mathrm{Hg}$ concentrations than the benthic (reference vertical distribution in the GAM) or benthopelagic species (Table 2, Fig. 4). Within the depth layer factor, species trawled in depth layers $200-599 \mathrm{~m}$ and $\geq 600 \mathrm{~m}$ presented significantly higher $\mathrm{Hg}$ 
concentrations than species from lower depth layers, that is, $<30 \mathrm{~m}$ (reference depth layer in the GAM), 30-119 $\mathrm{m}$ and 120-199 $\mathrm{m}$ (Table 2, Fig. 4). Finally, significantly higher $\mathrm{Hg}$ concentrations were found in Chondrichthyan fish relative to Actinopterygian fish (reference taxa in the GAM), and in comparison with crustacean and mollusc taxa (Table 2, Fig. 4). Mollusc taxa effectively presented the lowest $\mathrm{Hg}$ concentrations compared to other taxa (Fig. 4), and although non-significant the p-value for mollusc taxa was very low (Table 2). Finally, at the species scale, when considering low TP species whose individuals could be trawled in different depth layers (i.e., P. maximus and S. lignarius), individuals trawled inshore, near the coast or on the shelf (mostly layer 30-119 m) displayed significantly lower $\mathrm{Hg}$ concentrations than those trawled offshore, on the shelf edge (layer 120-199 m) (Wilcoxon test, $\mathrm{p}=0.012$ and $\mathrm{p}=0.005$ for $P$. maximus and $S$. lignarius respectively; see mean values in Table 1).

\section{Discussion}

$\mathrm{Hg}$ is a metal of particular concern in the marine environment because it has no known biological function and is toxic to all living organisms including human consumers (Eisler, 1987; Boening, 2000; WHO, 2003, 2010). However, in the Bay of Biscay, very few studies have investigated the levels of $\mathrm{Hg}$ contamination of biological components constituting the different food webs, although this system is an important marine area from ecological and economical points of view (OSPAR, 2010). Moreover, previous studies only focused on a limited number of species, such as coastal and/or mollusc species (e.g., Claisse et al., 2001; Bustamante et al., 2006), or are not recent (e.g., Cossa et al., 1990 and references therein). Thus, this study is the first to assess the $\mathrm{Hg}$ contamination level of a wide variety of organisms, as 120 species belonging to four major taxa (i.e., Actinopterygian fish, 
Chondrichthyan fish, crustaceans, molluscs) have been analysed for muscle $\mathrm{Hg}$ concentrations. These species are representative of the various habitats that such a marine ecosystem may present, that is, from coastal and neritic domains to oceanic and deep-sea domains (Fig. 1).

\subsection{Trophic positions and their limited effect on higher Hg bioaccumulation}

The food chain length (FCL) represents an important regulator of community and ecosystems function (Post and Takimoto, 2007; Vander Zanden and Fetzer, 2007). In this study, we consider the FCL to be the maximum TP in the pool of apex predators in an ecosystem. Indeed, it is the most commonly used definition; it is based on patterns of energy or material flow and thus it can be estimated in natural food webs using SIA (Post et al., 2000; Post and Takimoto, 2007; Vander Zanden and Fetzer, 2007). Moreover, as $\mathrm{Hg}$ is the only one metal whose biomagnification in food webs is now well admitted and not disputed (Gray, 2002), the use of SIA (tracing organic material fluxes in food webs) and the consideration of several trophic levels to study $\mathrm{Hg}$ behaviour in food webs are particularly appropriated (Vander Zanden and Rasmussen, 1996; Wang, 2002).

In this study, the maximum TP calculated from SIA was that of the marbled electric ray T. marmorata $(\mathrm{TP}=5.0)$. This is in accordance with the general distribution of FCL that may be calculated by this method in marine ecosystems, when marine mammals are excluded (Vander Zanden and Fetzer, 2007). Then, muscle Hg concentrations analysed in the 120 species from the Bay of Biscay revealed that these concentrations increased with the TP of species in the food webs of interest (Fig. 4), despite a non-significant effect of TP in the model. Indeed, the lack of significance of TP in the model is probably influenced by the few high TP species in which $\mathrm{Hg}$ concentrations are low (e.g., T. marmorata with a $\mathrm{TP}=5.0$ and 
an average $\mathrm{Hg}$ concentration $=151 \pm 99 \mathrm{n} \cdot \mathrm{g}^{-1} \mathrm{dwt}$; see Table 1). Thus, in higher TP consumers in particular, the high variability of muscle $\mathrm{Hg}$ concentrations suggests that the TP alone does not suffice to explain such differences in metal accumulation. Among the three factors tested in the model besides TP, the distribution in the water column effectively appeared to be the most important factor in explaining $\mathrm{Hg}$ variability, followed by the depth layer of sampling and finally the taxa. In fact, the importance of the water column distribution in explaining muscle $\mathrm{Hg}$ concentrations variability may be partly biased by a relative subjectivity or uncertainty when defining a species as a "true" pelagic, benthopelagic or benthic species. Indeed, for instance, some species may perform specific vertical migrations in the water column to feed (e.g., diel migrations; Roe and Badcock, 1984). So, for highly mobile species in general, it is difficult to categorically assess their distribution in the water column, and many species of our study thus belong to the category "benthopelagic" including many high TP consumers with elevated $\mathrm{Hg}$ concentrations in the muscle. On the contrary, the classification of species in one of the categories for both others factors, depth layer of sampling and taxa, is totally objective. In this way, the effect of those factors in explaining muscle $\mathrm{Hg}$ concentrations variability is less questionable, even if a slightly higher proportion of high $\mathrm{TP}$ consumers with potentially higher $\mathrm{Hg}$ concentrations may be found in species sampled deeper in particular (i.e., beyond $200 \mathrm{~m}$ depth (Fig. 3) and could have influenced the depth effect. However, the model calculates the effect of each variable once the effect of all other explanatory variables has been taken into account.

In fact, more generally, two principal types of factors may influence differences in metal concentrations between individuals of the same species or between species: 1) "metabolic" factors (in the broad sense of the term), including for example the age of organisms (e.g., Monteiro and Lopes, 1990), the different detoxification mechanisms (e.g., Rainbow, 2002), or the dilution due to growth (e.g., Pierce et al., 2008); 2) "exposure" factors, via the abiotic 
environment, through respiration for example, or via food, especially for metals which are mainly transferred by the trophic pathway such as $\mathrm{Hg}$ (e.g., Mathews and Fisher, 2008; Lacoue-Labarthe et al., 2009). Exposure factors via food thus include the concentration and the bioavailability of the metal in the prey consumed (e.g., Bustamante et al., 2002) or the trophic level of prey, for instance. In natural systems where the different parameters cannot be controlled, the importance of one type of factor or the other (i.e., metabolic or exposure) remains difficult to assess. In this study, we included in the model one metabolic factor (i.e., taxa), and three exposure factors (species' TPs, depth layer of sampling, and water column distribution) to explain variability in $\mathrm{Hg}$ concentrations. However, age would remain a factor of major importance for $\mathrm{Hg}$ accumulation (principally in its methylated form; Fitzgerald et al., 2007) in the muscle of numerous marine organisms (e.g., Monteiro and Lopes, 1990; Rossi et al., 1993; Cronin et al., 1998).

\subsection{Interaction between biological and environmental factors on $\mathrm{Hg}$}

\section{bioaccumulation}

In this study, to minimize such the possible bias due to the age of organisms, we only considered adult and mature individuals within each species, and sampled a relatively narrow range of sizes for most of the species analysed (Chouvelon et al., 2011). However, this does not really account for the fact that individuals of the different species analysed and compared may be of very different ages as a function of species' own longevities. If age-length keys are available and widely applicable for most of commercial species in general, this is not the case for less studied species and for deep-sea species in particular. Indeed, in those deep-sea species, uncertainties still exist in the determination of age (Allain and Lorance, 2000; Cailliet et al., 2001). In relation to this, the fact that molluscs and especially cephalopod molluscs of 
relatively high $\mathrm{TP}$ present very low muscle $\mathrm{Hg}$ concentrations in comparison with fish of the same TP and those of the deep-sea fauna in particular may be also linked to the age of organisms. Indeed, cephalopods are known to be short-lived species (i.e., the majority of species live for one to a few years, except for nautilus which can live for more than 20 years; Calow, 1987; Wood and O'Dor, 2000). As for deep-sea fish species (e.g., some Sebastidae or the orange roughy Hoplostethus atlanticus), they may live for more than 100 years (Allain and Lorance, 2000; Cailliet et al., 2001). This explains, at least in part, the enhanced bioaccumulation of $\mathrm{Hg}$ in these deep-sea species.

In addition to age, other potentially important factors for high muscle $\mathrm{Hg}$ accumulation could not be included in the model because of lack of data. For instance, other metabolic factors such as the different processes of detoxification that may occur in the different organisms or other biological factors that could greatly influence the exposure to $\mathrm{Hg}$ such as the specific ingestion rates of the different species (i.e., other than their TPs or their feeding zones through their general distribution). Modelling muscle $\mathrm{Hg}$ concentrations by GAM, we estimate that model residuals (i.e., the $\mathrm{Hg}$ variability not explained by the variables included) may reflect, at least in part, the importance of factors whose importance is difficult to quantify or cannot be controlled in situ. Thus, in our GAM model run on the 120 species analysed, the explained variability in muscle $\mathrm{Hg}$ concentrations is $52.4 \%$. This clearly suggests the importance of other factors that could not be included such as those mentioned above (e.g., age of organisms).

However, we should not forget that the production of methyl-Hg and of monomethyl-Hg in particular may be enhanced in sub-thermocline low oxygen waters (Bacci, 1989; Mason et al., 1995). Moreover, this organic form of $\mathrm{Hg}$ is a very stable form, the most bioavailable form and the form that is most accumulated by marine organisms (Fitzgerald et al., 2007). Indeed, 
our results highlight a higher $\mathrm{Hg}$ bioaccumulation by mesopelagic, bathypelagic, and bathydemersal species (particularly in fish species). Thus, it may be linked to a higher exposure to methyl-Hg in deep-water environments, as suggested by other authors in other areas of the world (Monteiro et al., 1996; Thompson et al., 1998; Ochoa-Acuña et al., 2002; Choy et al., 2009). Furthermore, considering a mean moisture content of about $75 \%$ in fish muscle (from dry weight/wet weight ratios measured in our samples) and that virtually $100 \%$ of total-Hg is in the methyl-Hg form in fish muscle (Bloom, 1992), a number of deep-sea species in particular present a health risk when consumed regularly. For instance, with a

muscle $\mathrm{Hg}$ concentration of over $1500 \mathrm{ng} \cdot \mathrm{g}^{-1} \mathrm{dwt}$, less than $300 \mathrm{~g}$ of flesh consumed by a 60 $\mathrm{kg}$ adult per week is thus sufficient to exceed the Provisional Tolerable Weekly Intake allocated by the JECFA (Joint FAO/WHO Expert Committee on Food Additives) for methylHg (European Commission, 2001; WHO, 2003, 2010; detailed calculation of Maximum Safe Weekly Consumption can be found in Chouvelon et al., 2009).

\section{Conclusion}

Analyses of muscle $\mathrm{Hg}$ concentrations in 120 species from various taxa and from various habitats of an open marine ecosystem, the Bay of Biscay in the north-eastern Atlantic, revealed that the feeding zone plays an important role in influencing $\mathrm{Hg}$ accumulation by organisms. Thus, deep-sea species present particularly high levels of $\mathrm{Hg}$ in their flesh, and long-term consumption of deep-sea fish in particular may therefore present a risk for human health. To confirm such enhanced $\mathrm{Hg}$ bioaccumulation in deep-water environments, the inclusion of high trophic level marine mammals inhabiting the different habitats of the Bay of Biscay might improve the accumulation model. In this case and more generally, the age of 
organisms or other potentially important factors (e.g., ingestion rates) should also be included in the model.

\section{Acknowledgments}

This work was supported through the $\mathrm{PhD}$ grant of $\mathrm{T}$. Chouvelon from the Conseil Régional de Poitou-Charentes, and by the Contrat de Projet Etat-Région (CPER 13). Authors are very grateful to J.P. Léauté, R. Bellail, M. Salaun and P. Lorance from IFREMER for facilitating the sampling, and the crew of the R/V "Thalassa" for their support during the EVHOE cruises. They also thank P. Richard, G. Guillou and C. Churlaud (UMR LIENSs) for assistance in stable isotope and metal analysis, finally C. Pignon-Mussaud from the Cellule Géomatique (UMR LIENSs) for providing the map of the study area.

\section{References}

Allain, V., Lorance, P., 2000. Age estimation and growth of some deep-sea fish from the Northeast Atlantic Ocean. Cybium 24, 7-16.

Bacci, E., 1989. Mercury in the Mediterranean. Marine Pollution Bulletin 20, 59-63.

Bloom, N.S., 1992. On the chemical form of mercury in edible fish and marine invertebrate tissue. Canadian Journal of Fisheries and Aquatic Science 49, 1010-1017.

Boening, D., 2000. Ecological effects, transport, and fate of mercury: a general review. Chemosphere 40, 1335-1351.

Borja, A., Galparsoro, I., Irigoien, X., Iriondo, A., Menchaca, I., Muxika, I., Pascual, M., Quincoces, I., Revilla, M., Rodríguez, J.G., Santurtún, M., Solaun, O., Uriarte, A., Valencia, 
V., Zorita, I., 2011. Implementation of the European Marine Strategy Framework Directive: a methodological approach for the assessment of environmental status, from the Basque Country (Bay of Biscay). Marine Pollution Bulletin 62, 889-904.

Bustamante, P., Cosson, R.P., Gallien, I., Caurant, F., Miramand, P., 2002. Cadmium detoxification processes in the digestive gland of cephalopods in relation to accumulated cadmium concentrations. Marine Environmental Research 53, 227-241.

Bustamante, P., Lahaye, V., Durnez, C., Churlaud, C., Caurant, F., 2006. Total and organic $\mathrm{Hg}$ concentrations in cephalopods from the North Eastern Atlantic waters: influence of geographical origin and feeding ecology. Science of the Total Environment 368, 585-596.

Cailliet, G.M., Andrews, A.H., Burton, E.J., Watters, D.L., Kline, D.E., Ferry-Graham, L.A., 2001. Age determination and validation studies of marine fishes: do deep-dwellers live longer? Experimental Gerontology 36, 739-764.

Calow, P., 1987. Fact and theory - an overview. In: Boyle, P.R. (Ed.), Cephalopod life cycles: comparative reviews. Vol. 2, Academic Press, London, pp 351-366.

Caut, S., Angulo, E., Courchamp, F., 2009. Variation in discrimination factors $(\Delta 15 \mathrm{~N}$ and $\Delta 13 \mathrm{C})$ : the effect of diet isotopic values and applications for diet reconstruction. Journal of Applied Ecology 46, 443-453.

Cherel, Y., Hobson, K.A., Hassani, S., 2005. Isotopic discrimination between food and blood and feathers of captive penguins: implication for dietary studies in the wild. Physiological and Biochemical Zoology 78, 106-115.

Chouvelon, T., Spitz, J., Caurant, F., Mèndez-Fernandez, P., Chappuis, A., Laugier, F., Le Goff, E., Bustamante, P., (in press). Spatio-temporal variations in stable isotopic signatures revisit the use of $\delta^{15} \mathrm{~N}$ in mesoscale studies of marine food webs. The case of an open ecosystem: the Bay of Biscay (North-East Atlantic). Progress in Oceanography. 
Chouvelon, T., Spitz, J., Cherel, Y., Caurant, F., Sirmel, R., Mèndez-Fernandez, P., Bustamante, P., 2011. Inter-specific and ontogenic differences in $\delta^{13} \mathrm{C}$ and $\delta^{15} \mathrm{~N}$ values and $\mathrm{Hg}$ and Cd concentrations in cephalopods. Marine Ecology Progress Series 433, 107-120.

Chouvelon, T., Warnau, M., Churlaud, C., Bustamante, P, 2009. Hg concentrations and related risk assessment in coral reef crustaceans, molluscs and fish from New Caledonia. Environmental Pollution 157, 331-340.

Choy, C.A., Popp, B.N., Kaneko, J.J., Drazen, J.C., 2009. The influence of depth on mercury levels in pelagic fishes and their prey. Proceedings of the National Academy of Science USA $106,13865-13869$.

Claisse, D., Cossa, D., Bretaudeau-Sanjuan, J., Touchard, G., Bombled, B., 2001. Methylmercury in molluscs along the French coast. Marine Pollution Bulletin 42, 329-332.

Cossa, D., Thibaud, Y., Roméo, M., Gnassia-Barelli, M., 1990. Le mercure en milieu marin. Biogéochimie et écotoxicologie. Rapports Scientifiques et Techniques de l'IFREMER 19, Brest, France, 130 p.

Cronin, M., Davies, I.M., Newton, A., Pirie, J.M., Topping, G., Swan, S., 1998. Trace metal concentrations in deep sea fish from the North Atlantic. Marine Environmental Research 45, 225-238.

Curtin, R., Prellezo, R., 2010 Understanding marine ecosystem based management: a literature review. Marine Policy 34, 821-830.

Cury, P., Shannon, L., Shin, Y.J., 2003. The functioning of marine ecosystems: a fisheries perspective. In: Sinclair, M., Valdimarsson, G. (Eds.), Responsible fisheries in the marine ecosystem. CAB International, Walingford, pp 103-123.

De Niro, M.J., Epstein, S., 1977. Mechanism of carbon fractionation associated with lipid synthesis. Science 197, 261-263. 
De Niro, M.J., Epstein, S., 1978. Influence of diet on the distribution of carbon isotopes in animals. Geochimica et Cosmochimica Acta 42, 495-506.

De Niro MJ, Epstein S (1981) Influence of diet on the distribution of nitrogen isotopes in animals. Geochimica et Cosmochimica Acta 45, 341-351.

Eisler, R., 1987. Mercury hazards to fish, wildlife, and invertebrates: a synoptic review. US Fish and Wildlife Service Biological Report 85 (1.10).

European Commission, 2001. Commission Regulation (EC) No 466/2001 of 8 March 2001, setting maximum levels for certain contaminants in foodstuffs. Official Journal of the European Communities L77, pp 1-13.

European Commission, 2008. Directive 2008/56/EC of the European Parliament and of the Council of 17 June 2008, establishing a framework for community action in the field of marine environmental policy (Marine Strategy Framework Directive). Official Journal of the European Union L 164, pp 19-40.

European Commission, 2010. Commission Decision of 1 September 2010 on criteria and methodological standards on good environmental status of marine waters. Official Journal of the European Union L 232, pp 14-24.

Fitzgerald, W.F., Lamborg, C.H., Hammerschmidt, C.R., 2007. Marine biogeochemical cycling of mercury. Chemical Review 107, 641-662.

France, R.L., 1995. Carbon-13 enrichment in benthic compared to planktonic algae: food web implications. Marine Ecology Progress Series 124, 307-312.

Gray, J.S., 2002. Biomagnification in marine systems: the perspective of an ecologist. Marine Pollution Bulletin 45, 46-52.

Hobson, K.A., 1999. Tracing origins and migration of wildlife using stable isotopes: a review. Oecologia 120, 314-326. 
Hobson, K.A., Cherel, Y., 2006. Isotopic reconstruction of marine food webs using cephalopod beaks: new insight from captively raised Sepia officinalis. Canadian Journal of Zoology 84, 766-770.

Hobson, K.A., Welch, H.E., 1992. Determination of trophic relationships within a high Arctic marine food web using $\delta^{13} \mathrm{C}$ and $\delta^{15} \mathrm{~N}$ analysis. Marine Ecology Progress Series 84, 9-18.

Hussey, N.E., Brush, J., McCarthy, I.D., Fisk, A.T., 2010. $\delta^{15} \mathrm{~N}$ and $\delta^{13} \mathrm{C}$ diet-tissue discrimination factors for large sharks under semi-controlled conditions. Comparative Biochememistry and Physiology, Part A 155, 445-453.

Hussey, N.E., MacNeil, M.A., Fisk, A.T., 2010. The requirement for accurate diet-tissue discrimination factors for interpreting stable isotopes in sharks. Comment on: stable isotope dynamics in elasmobranch fishes. Hydrobiologia 654, 1-5.

Jennings, S., Pinnegar, J.K., Polunin, N.V.C., Boon, T.V., 2001. Weak cross-species relationships between body size and trophic level belie powerful size-based trophic structuring in fish communities. Journal of Animal Ecology 70, 934-944.

Karpouzi, V.S,. Stergiou, K.I., 2003. The relationships between mouth size and shape and body length for 18 species of marine fishes and their trophic implications. Journal of Fish Biology 62, 1353-1365.

Koutsikopoulos, C., Le Cann, B., 1996. Physical processes and hydrological structures related to the Bay of Biscay anchovy. Scientia Marina 60, 9-19.

Lacoue-Labarthe, T., Warnau, M., Oberhänsli, F., Teyssié, J.L., Bustamante, P., 2009. Bioaccumulation of inorganic $\mathrm{Hg}$ by the juvenile cuttlefish Sepia officinalis exposed to ${ }^{203} \mathrm{Hg}$ radiolabelled seawater and food. Aquatic Biology 6, 91-98.

Larkin, P.A., 1996. Concepts and issues in marine ecosystem management. Reviews in Fish Biology and Fisheries 6, 139-164. 
Lavoie, R.A., Hebert, C.E., Rail, J.F., Braune, B.M., Yumvihoze, E., Hill, L.G., Lean, D.R.S., 2010. Trophic structure and mercury distribution in a Gulf of St. Lawrence (Canada) food web using stable isotope analysis. Science of the Total Environment 408, 5529-5539.

Le Loc'h, F., Hily, C., Grall, J., 2008. Benthic community and food web structure on the continental shelf of the Bay of Biscay (North Eastern Atlantic) revealed by stable isotopes analysis. Journal of Marine Systems 72, 17-34.

Lesage, V., O’Hammill, M., Kovacs, K.M., 2001. Marine mammals and the community structure of the Estuary and Gulf of St Lawrence, Canada: evidence from stable isotope analysis. Marine Ecology Progress Series 210, 203- 221.

Logan, J.M., Lutcavage, M.E., 2010. Stable isotope dynamics in elasmobranch fishes. Hydrobiologia 644, 231-244.

Lorance, P., Bertrand, J.A., Brind'Amour, A., Rochet, M.J., Trenkel, V.M., 2009. Assessment of impacts from human activities on ecosystem components in the Bay of Biscay in the early 1990s. Aquatic Living Resources 22, 409-431.

Lorance, P., Latrouite, D., Séret, B., 2000. Observations of Chondrichthyan fishes (sharks, rays and chimaeras) in the Bay of Biscay (North-Eastern Atlantic) from submersibles. Proceedings of the $3^{\text {rd }}$ European Elasmobranch Association Meeting, Boulogne sur Mer, France, pp. 29-45.

Mason, R.P., Rolfhus, K.R., Fitzgerald, W.F., 1995. Methylated and elemental mercury cycling in surface and deep ocean waters of the North Atlantic. Water Air Soil Pollution 80, 665-677.

Mathews, T., Fisher, N.S., 2008. Evaluating the trophic transfer of cadmium, polonium, and methylmercury in an estuarine food chain. Environmental Toxicology and Chemistry 27, 1093-1101. 
Michener, R.H., Kaufman, L., 2007. Stable isotope ratios as tracers in marine food webs: an update. In: Michener, R., Lajtha, K. (Eds.), Stable isotopes in ecology and environmental science. Blackwell Publishing Ltd, pp 238-282.

Monteiro, L.R., Costa, V., Furness, R.W., Santos, R.S., 1996. Mercury concentrations in prey fish indicate enhanced bioaccumulation in mesopelagic environments. Marine Ecology Progress Series 141, 21-25.

Monteiro, L.R., Lopes, H.D., 1990. Mercury content of swordfish, Xiphias gladius, in relation to length, weight, age, and sex. Marine Pollution Bulletin 21, 293-296.

Ochoa-Acuña, H., Sepúlveda, M.S., Gross, T.S., 2002. Mercury in feathers from Chilean birds: influence of location, feeding strategy, and taxonomic affiliation. Marine Pollution Bulletin 44, 340-349.

OSPAR (2010) Quality Status Report 2010. OSPAR Commission, London, 176 p.

Palomares, M.L.D., Pauly, D. (Eds.), 2010. SeaLifeBase, World Wide Web electronic publication, www.sealifebase.org, version (12/2010).

Peterson, B.J., Fry, B., 1987. Stable isotopes in ecosystem studies. Annual Review of Ecology and Systematics 18, 293-320.

Pierce, G.J., Stowasser, G., Hastie, L.C., Bustamante, P., 2008. Geographic, seasonal and ontogenetic variation in cadmium and mercury concentrations in squid (Cephalopoda: Teuthoidea) from UK waters. Ecotoxicology and Environmental Safety 70, 422-432.

Pinnegar, J.K., Polunin, N.V.C., 1999. Differential fractionation of $\delta^{13} \mathrm{C}$ and $\delta^{15} \mathrm{~N}$ among fish tissues: implications for the study of trophic interactions. Functional Ecology 13, 225-231.

Planque, B., Lazure, P., Jégou, A.M., 2004. Detecting hydrological landscapes over the Bay of Biscay continental shelf in spring. Climate Research 28, 41-52.

Post, D.M., 2002a. Using stable isotopes to estimate trophic position: models, methods and assumptions. Ecology 83, 703-718. 
Post, D.M., 2002b. The long and short of food-chain length. Trends in Ecology and Evolution 17, 269-277.

Post, D.M., Pace ML, Hairston NGJ (2000) Ecosystem size determines food-chain length in lakes. Nature 405, 1047-1049.

Post, D.M., Takimoto, G., 2007. Proximate structural mechanisms for variation in food-chain length. Oikos 116, 775-782.

Puillat, I., Lazure, P., Jégou, A.M., Lampert, L., Miller, P.I., 2004. Hydrographical variability on the French continental shelf in the Bay of Biscay, during the 1990s. Continental Shelf Research 24, 1143-1163.

Quéro, J.C., 2003. Guide des Poissons de l'Atlantique Européen. Les guides du naturaliste. Delachaux and Niestlé (Eds.), Paris, France.

R Development Core Team (2010) R: a language and environment for statistical computing. R Foundation for Statistical Computing, Vienna, www.R-project.org.

Rainbow, P.S., 2002. Trace metal concentrations in aquatic invertebrates: why and so what? Environmental Pollution 120, 497-507.

Reinfelder, J.R., Fisher, N.S., Luoma, S.N., Nichols, J.W., Wang, W.X., 1998. Trace element trophic transfer in aquatic organisms: a critique of the kinetic model approach. Science of the Total Environment 219, 117-135.

Roe, H.S.J., Badcock, J., 1984. The diel migrations and distributions within a mesopelagic community in the North East Atlantic. 5. Vertical migrations and feeding of fish. Progress in Oceanography $13,389-424$.

Rossi, A., Pellegrini, D., Belcari, P., Barghigiani, C., 1993. Mercury in Eledone cirrhosa from the Northern Tyrrhenian Sea: contents and relations with life cycle. Marine Pollution Bulletin 26, 683-686. 
Suring, E., Wing, S.R., 2009. Isotopic turnover rate and fractionation in multiple tissues of red rock lobster (Jasus edwardsii) and blue cod (Parapercis colias): Consequences for ecological studies. Journal of Experimental Marine Biology and Ecology 370, 56-63.

Sweeting, C.J., Barry, J., Barnes, C., Polunin, N.V.C., Jennings, S., 2007. Effects of body size and environment on diet-tissue $\delta^{15} \mathrm{~N}$ fractionation in fishes. Journal of Experimental Marine Biology and Ecology 340, 1-10.

Thompson, D.R., Furness, R.W., Monteiro, L.R., 1998. Seabirds as biomonitors of mercury inputs to epipelagic and mesopelagic marine food chains. Science of the Total Environment 213, 299-305.

Trenkel, V.M., Berthelé, O., Lorance, P., Bertrand, J., Brind'Amour, A., Cochard, M.L., Coppin, F., Léauté, J.P., Mahé, J.C., Morin, J., Rochet, M.J., Salaun, M., Souplet, A., Vérin, Y., 2009. Atlas des grands invertébrés et poissons observés par les campagnes scientifiques. Bilan 2008. Ifremer, Nantes, EMH: 09-003, 100 p.

Vanderklift, M.A., Ponsard, S., 2003. Source of variation in consumer-diet $\delta^{15} \mathrm{~N}$ enrichment: a meta-analysis. Oecologia 136, 169-182.

Vander Zanden, M.J., Rasmussen, J.B., 1996. A trophic position model of pelagic food webs: impact on contaminant bioaccumulation in lake trout. Ecological Monographs 66, 451-477.

Vander Zanden, M.J., Fetzer, W.W., 2007. Global patterns of aquatic food chain length. Oikos 116, 1378-1388.

Wang, W.X., 2002. Interactions of trace metals and different marine food chains. Marine Ecology Progress Series 243, 295-309.

WHO, 2003. Joint FAO/WHO Expert Committee on Food Additives, Sixty-first meeting. Summary and conclusions, $22 \mathrm{p}$.

WHO, 2010. Joint FAO/WHO Expert Committee on Food Additives, Seventy-second meeting. Summary and conclusions, $16 \mathrm{p}$. 
Wood, J.B., O'Dor, R.K., 2000. Do larger cephalopods live longer? Effects of temperature and phylogeny on interspecific comparisons of age and size at maturity. Marine Biology 136, 91-99.

Yokoyama, H., Tamaki, A., Harada, K., Shimoda, K., Koyama, K., Ishihi, Y., 2005. Variability of diet-tissue isotopic fractionation in estuarine macrobenthos. Marine Ecology Progress Series 296, 115-128.

Zuur, A.F., Ieno, E.N., Smith, G.M., 2007. Analysing Ecological Data. Springer, New York. 
Table 1: Characteristics of studied species from the Bay of Biscay: distribution, average trawling depth, number of individuals $(\mathrm{N})$, size of individuals, stable isotopes-derived trophic position (TP), and $\mathrm{Hg}$ concentrations in the muscle. The mean TP of each major taxa considered in also given (in bold). Species are classified by taxa, then by depth layer of sampling, then distribution in the water column, then TP, finally by increasing $\mathrm{Hg}$ concentrations (see detailed grouping strategy in Materials sand Methods). $\mathrm{SD}=$ Standard Deviation. $\mathrm{N}=$ number of individuals.

\begin{tabular}{|c|c|c|c|c|c|c|c|}
\hline \multirow[t]{2}{*}{ Taxa and species } & \multirow[t]{2}{*}{$\mathbf{N}$} & \multirow[t]{2}{*}{$\begin{array}{l}\text { Depth } \\
\text { layer }^{\mathrm{a}}\end{array}$} & \multirow{2}{*}{$\begin{array}{l}\text { Depth } \\
(\mathbf{m})^{\mathrm{b}}\end{array}$} & \multirow[t]{2}{*}{$\begin{array}{c}\text { Water } \\
\text { column } \\
\text { distribution }\end{array}$} & \multirow{2}{*}{$\begin{array}{l}\text { Size }(\mathbf{m m})^{\mathrm{d}} \\
\text { Mean } \pm \mathrm{SD}\end{array}$} & \multirow{2}{*}{$\begin{array}{c}\text { TP } \\
\text { Mean } \pm \\
\text { SD }\end{array}$} & \multirow{2}{*}{$\begin{array}{c}\text { Hg concentration in the } \\
\text { muscle }\left(\text { ng. } \text { g }^{-1} \text { dwt }\right) \\
\text { Mean } \pm \text { SD } \\
(\text { min-max })\end{array}$} \\
\hline & & & & & & & \\
\hline \multicolumn{8}{|l|}{ FISH } \\
\hline \multicolumn{8}{|l|}{ Actinopterygians } \\
\hline $\begin{array}{l}\text { Dicentrarchus labrax }(\leq 400 \\
m m T L)\end{array}$ & 6 & $<30 \mathrm{~m}$ & 29 & $\mathrm{bp}$ & $373 \pm 23$ & $3.6 \pm 0.1$ & $672 \pm 168(398-841)$ \\
\hline Labrus bergylta & 3 & $<30 \mathrm{~m}$ & 20 & bp & $507 \pm 25$ & $4.3 \pm 0.0$ & $1001 \pm 192(865-1220)$ \\
\hline Engraulis encrasicolus & 5 & $<30 \mathrm{~m}$ & 25 & $\mathrm{p}$ & $124 \pm 11$ & $3.9 \pm 0.2$ & $178 \pm 55(123-268)$ \\
\hline Sprattus sprattus & 5 & $<30 \mathrm{~m}$ & 28 & $\mathrm{p}$ & $86 \pm 5$ & $4.0 \pm 0.2$ & $59 \pm 12(50-80)$ \\
\hline Atherina presbyter & 5 & $<30 \mathrm{~m}$ & 25 & $\mathrm{p}$ & $110 \pm 10$ & $4.2 \pm 0.1$ & $189 \pm 69(116-276)$ \\
\hline Solea solea & 27 & $30-119 \mathrm{~m}$ & 53 & $\mathrm{~b}$ & $316 \pm 59$ & $3.3 \pm 0.3$ & $556 \pm 602(92-1739)$ \\
\hline Dicologlossa cuneata & 5 & $30-119 \mathrm{~m}$ & 60 & $\mathrm{~b}$ & $188 \pm 16$ & $3.8 \pm 0.2$ & $427 \pm 201(197-712)$ \\
\hline Microchirus variegatus & 5 & $30-119 \mathrm{~m}$ & 47 & $\mathrm{~b}$ & $162 \pm 8$ & $3.8 \pm 0.1$ & $1152 \pm 150(996-1340)$ \\
\hline Callionymus lyra & 5 & $30-119 \mathrm{~m}$ & 109 & bp & $222 \pm 16$ & $3.5 \pm 0.1$ & $450 \pm 68(378-551)$ \\
\hline Trachinus draco & 9 & $30-119 \mathrm{~m}$ & 39 & $\mathrm{bp}$ & $236 \pm 21$ & $3.8 \pm 0.1$ & $276 \pm 160(101-636)$ \\
\hline Argentina sphyraena & 5 & $30-119 \mathrm{~m}$ & 109 & $\mathrm{bp}$ & $194 \pm 11$ & $3.8 \pm 0.2$ & $396 \pm 261(208-842)$ \\
\hline Trisopterus minutus & 25 & $30-119 \mathrm{~m}$ & 104 & $\mathrm{bp}$ & $183 \pm 14$ & $3.9 \pm 0.1$ & $469 \pm 414(146-1988)$ \\
\hline Echiichthys vipera & 5 & $30-119 \mathrm{~m}$ & 47 & $\mathrm{bp}$ & $108 \pm 8$ & $3.9 \pm 0.1$ & $523 \pm 169(326-720)$ \\
\hline Eutrigla gurnardus & 18 & $30-119 \mathrm{~m}$ & 114 & $\mathrm{bp}$ & $311 \pm 62$ & $3.9 \pm 0.1$ & $849 \pm 512(301-2277)$ \\
\hline Lesueurigobius friesii & 5 & $30-119 \mathrm{~m}$ & 60 & $\mathrm{bp}$ & $76 \pm 5$ & $4.0 \pm 0.1$ & $125 \pm 27(83-155)$ \\
\hline Gadiculus argenteus & 5 & $30-119 \mathrm{~m}$ & 47 & $\mathrm{bp}$ & $110 \pm 7$ & $4.0 \pm 0.1$ & $259 \pm 33(215-296)$ \\
\hline Boops boops & 5 & $30-119 \mathrm{~m}$ & 99 & $\mathrm{bp}$ & $262 \pm 24$ & $4.0 \pm 0.4$ & $306 \pm 101(145-387)$ \\
\hline Trisopterus luscus & 14 & $30-119 \mathrm{~m}$ & 63 & $\mathrm{bp}$ & $180 \pm 30$ & $4.0 \pm 0.1$ & $389 \pm 215(161-943)$ \\
\hline Dicentrarchus punctatus & 4 & $30-119 \mathrm{~m}$ & 36 & $\mathrm{bp}$ & $357 \pm 15$ & $4.0 \pm 0.2$ & $1140 \pm 45(1081-1187)$ \\
\hline Pomatoschistus minutus & 5 & $30-119 \mathrm{~m}$ & 60 & $\mathrm{bp}$ & $56 \pm 5$ & $4.1 \pm 0.1$ & $65 \pm 6(55-71)$ \\
\hline Cepola macrophthalma & 5 & $30-119 \mathrm{~m}$ & 109 & $\mathrm{bp}$ & $554 \pm 18$ & $4.1 \pm 0.1$ & $162 \pm 54(104-245)$ \\
\hline Merlangius merlangus & 15 & $30-119 \mathrm{~m}$ & 55 & $\mathrm{bp}$ & $423 \pm 36$ & $4.1 \pm 0.1$ & $680 \pm 177(379-1065)$ \\
\hline Zeusfaber & 5 & $30-119 \mathrm{~m}$ & 116 & $\mathrm{bp}$ & $550 \pm 19$ & $4.1 \pm 0.1$ & $2031 \pm 485(1426-2783)$ \\
\hline Conger conger & 5 & $30-119 \mathrm{~m}$ & 67 & $\mathrm{bp}$ & $1278 \pm 88$ & $4.2 \pm 0.3$ & $1638 \pm 988(753-3310)$ \\
\hline $\begin{array}{l}\text { Dicentrarchus labrax } \quad(>400 \\
m m T L)\end{array}$ & 5 & $30-119 \mathrm{~m}$ & 98 & $\mathrm{bp}$ & $668 \pm 24$ & $4.2 \pm 0.1$ & $2725 \pm 763(1654-3701)$ \\
\hline Spondyliosoma cantharus & 7 & $30-119 \mathrm{~m}$ & 44 & $\mathrm{bp}$ & $254 \pm 34$ & $4.3 \pm 0.3$ & $325 \pm 143(182-554)$ \\
\hline Ammodytes tobianus & 5 & $30-119 \mathrm{~m}$ & 58 & $\mathrm{p}$ & $290 \pm 16$ & $3.7 \pm 0.1$ & $124 \pm 26(102-162)$ \\
\hline Scomber japonicus & 5 & $30-119 \mathrm{~m}$ & 43 & $\mathrm{p}$ & $338 \pm 19$ & $3.7 \pm 0.1$ & $198 \pm 37(142-237)$ \\
\hline Trachurus trachurus & 39 & $30-119 \mathrm{~m}$ & 106 & $\mathrm{p}$ & $284 \pm 61$ & $4.0 \pm 0.2$ & $461 \pm 299(115-1112)$ \\
\hline Hyperoplus lanceolatus & 5 & $30-119 \mathrm{~m}$ & 58 & $\mathrm{p}$ & $340 \pm 14$ & $4.0 \pm 0.1$ & $710 \pm 70(598-774)$ \\
\hline Lepidorhombus whiffiagonis & 5 & $120-199 \mathrm{~m}$ & 127 & $\mathrm{~b}$ & $432 \pm 24$ & $3.9 \pm 0.0$ & $655 \pm 569(252-1661)$ \\
\hline Chelidonichthys lucerna & 5 & $120-199 \mathrm{~m}$ & 137 & bp & $554 \pm 63$ & $3.8 \pm 0.2$ & $1180 \pm 191(964-1411)$ \\
\hline Aspitrigla cuculus & 5 & $120-199 \mathrm{~m}$ & 131 & $\mathrm{bp}$ & $254 \pm 11$ & $3.9 \pm 0.1$ & $486 \pm 100(354-627)$ \\
\hline Melanogrammus aeglefinus & 5 & $120-199 \mathrm{~m}$ & 163 & $\mathrm{bp}$ & $532 \pm 44$ & $3.9 \pm 0.4$ & $522 \pm 392(194-1180)$ \\
\hline $\begin{array}{l}\text { Lophius piscatorius }(400-700 \\
\text { mm TL) }\end{array}$ & 18 & $120-199 \mathrm{~m}$ & 193 & $\mathrm{bp}$ & $570 \pm 72$ & $4.1 \pm 0.1$ & $807 \pm 209(339-1230)$ \\
\hline $\begin{array}{l}\text { Merluccius merluccius } \\
550 \mathrm{~mm} T \mathrm{TL})\end{array}$ & 21 & $120-199 \mathrm{~m}$ & 140 & bp & $466 \pm 56$ & $4.3 \pm 0.1$ & $346 \pm 199(120-981)$ \\
\hline $\begin{array}{l}\text { Merluccius merluccius (>550 } \\
m m T L)\end{array}$ & 12 & $120-199 \mathrm{~m}$ & 127 & bp & $632 \pm 59$ & $4.3 \pm 0.1$ & $941 \pm 622(356-1954)$ \\
\hline Lophius budegassa & 5 & $120-199 \mathrm{~m}$ & 136 & bp & $746 \pm 88$ & $4.3 \pm 0.1$ & $1809 \pm 983(746-3410)$ \\
\hline Scorpaena scrofa & 4 & $120-199 \mathrm{~m}$ & 128 & bp & $400 \pm 45$ & $4.3 \pm 0.1$ & $3223 \pm 790(2552-4280)$ \\
\hline Sardina pilchardus & 25 & $120-199 \mathrm{~m}$ & 123 & $\mathrm{p}$ & $209 \pm 20$ & $3.8 \pm 0.3$ & $174 \pm 81(62-355)$ \\
\hline Scomber scombrus & 3 & $120-199 \mathrm{~m}$ & 150 & $\mathrm{p}$ & $300 \pm 10$ & $4.0 \pm 0.3$ & $201 \pm 42(154-235)$ \\
\hline Bathysolea profundicola & 5 & $200-599 \mathrm{~m}$ & 333 & $\mathrm{~b}$ & $192 \pm 13$ & $3.9 \pm 0.2$ & $2465 \pm 679(1377-3087)$ \\
\hline Argentina silus & 5 & $200-599 \mathrm{~m}$ & 492 & bp & $352 \pm 27$ & $3.6 \pm 0.1$ & $797 \pm 221(495-1073)$ \\
\hline Micromesistius & 5 & $200-599 \mathrm{~m}$ & 246 & $\mathrm{bp}$ & $320 \pm 7$ & $3.8 \pm 0.1$ & $594 \pm 170(354-771)$ \\
\hline
\end{tabular}


(>300 mm TL)

Micromesistius poutassou
(<300 mm TL)
Malacocephalus laevis
Beryx decadactylus
Phycis blennoides
Caelorhynchus caelorhynchus
Molva macrophtalma
Helicolenus dactylopterus
Lophius piscatorius (>700 mm
TL)
Trachyrincus scabrus
Polymetme thaeocoryla
Molva molva
Notoscopelus kroeyeri
Alepocephalus bairdii
Notacanthus bonaparte
Mora moro
Coryphaenoides rupestris
Nezumia aequalis
Lepidion eques
Alepocephalus rostratus
Normichthys operosa
Trachyscorpia cristulata
Hoplostethus atlanticus
Bathypterois dubius
Benthosema glaciale
Xenodermichthys copei
Lampanyctus crocodilus
Serrivomer beanii
Arctozenus risso
Ceratoscopolus maderensis
Argyropelecus olfersii
Bathylagus greyae
Myctophum punctatum
Stomias boa
Aphanopus carbo

$\begin{array}{ccc}34 & 200-599 \mathrm{~m} & 260 \\ 5 & 200-599 \mathrm{~m} & 337 \\ 6 & 200-599 \mathrm{~m} & 509 \\ 5 & 200-599 \mathrm{~m} & 259 \\ 5 & 200-599 \mathrm{~m} & 461 \\ 5 & 200-599 \mathrm{~m} & 492 \\ 5 & 200-599 \mathrm{~m} & 492 \\ 12 & 200-599 \mathrm{~m} & 313 \\ 5 & 200-599 \mathrm{~m} & 536 \\ 5 & 200-599 \mathrm{~m} & 506 \\ 4 & 200-599 \mathrm{~m} & 203 \\ 4 & 200-599 \mathrm{~m} & 496 \\ 5 & \geq 600 \mathrm{~m} & 1209 \\ 5 & \geq 600 \mathrm{~m} & 1010 \\ 5 & \geq 600 \mathrm{~m} & 1089 \\ 4 & \geq 600 \mathrm{~m} & 1142 \\ 5 & \geq 600 \mathrm{~m} & 1033 \\ 5 & \geq 600 \mathrm{~m} & 1177 \\ 5 & \geq 600 \mathrm{~m} & 1118 \\ 5 & \geq 600 \mathrm{~m} & 2250 \\ 5 & \geq 600 \mathrm{~m} & 1118 \\ 5 & \geq 600 \mathrm{~m} & 1153 \\ 5 & \geq 600 \mathrm{~m} & 1147 \\ 5 & \geq 600 \mathrm{~m} & 800 \\ 6 & \geq 600 \mathrm{~m} & 1129 \\ 5 & \geq 600 \mathrm{~m} & 2250 \\ 5 & \geq 600 \mathrm{~m} & 1033 \\ 5 & \geq 600 \mathrm{~m} & 1316 \\ 5 & \geq 600 \mathrm{~m} & 1316 \\ 5 & \geq 600 \mathrm{~m} & 1316 \\ 5 & \geq 600 \mathrm{~m} & 1980 \\ 5 & \geq 600 \mathrm{~m} & 1316 \\ 5 & \geq 600 \mathrm{~m} & 1033 \\ 5 & \geq 600 \mathrm{~m} & 1033\end{array}$

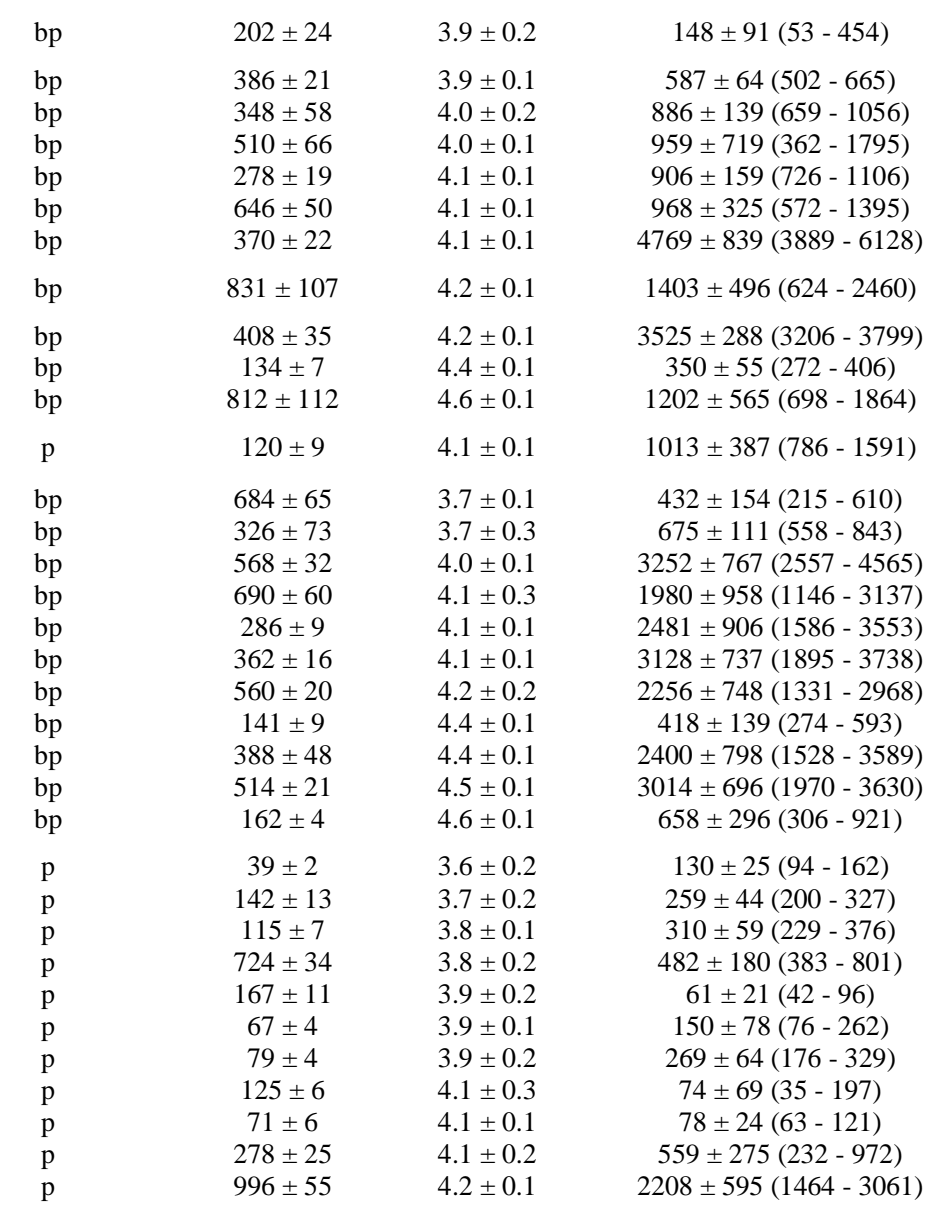

\section{Chondrichthyans}

Raja microocellata

Torpedo marmorata

Mustelus asterias

Mustelus mustelus

Raja clavata

Leucoraja naevus

Scyliorhinus canicula

Galeus melastomus

Etmopterus spinax

Hydrolagus mirabilis

Chimaera monstrosa

Centroselachus crepidater

Deania calcea

Deania profundorum

$\begin{array}{cccc}5 & <30 \mathrm{~m} & 21 & \mathrm{~b} \\ 3 & 30-119 \mathrm{~m} & 33 & \mathrm{~b} \\ 11 & 30-119 \mathrm{~m} & 112 & \mathrm{bp} \\ 4 & 30-119 \mathrm{~m} & 108 & \mathrm{bp} \\ & & & \mathrm{b} \\ 11 & 120-199 \mathrm{~m} & 128 & \mathrm{~b} \\ 10 & 120-199 \mathrm{~m} & 126 & \mathrm{bp} \\ 10 & 120-199 \mathrm{~m} & 126 & \\ & & & \mathrm{bp} \\ 12 & 200-599 \mathrm{~m} & 289 & \mathrm{bp} \\ 10 & 200-599 \mathrm{~m} & 492 & \mathrm{bp} \\ 5 & \geq 600 \mathrm{~m} & 1116 & \mathrm{bp} \\ 16 & \geq 600 \mathrm{~m} & 637 & \mathrm{bp} \\ 5 & \geq 600 \mathrm{~m} & 1147 & \mathrm{bp} \\ 10 & \geq 600 \mathrm{~m} & 1033 & \mathrm{bp} \\ 4 & \geq 600 \mathrm{~m} & 1033 & \end{array}$

$\begin{array}{cc}694 \pm 99 & 3.6 \pm 0.1 \\ 383 \pm 81 & 5.0 \pm 0.5 \\ 874 \pm 91 & 3.8 \pm 0.3 \\ 935 \pm 163 & 4.0 \pm 0.3 \\ 735 \pm 111 & 3.7 \pm 0.3 \\ 604 \pm 28 & 3.8 \pm 0.1 \\ 579 \pm 31 & 4.5 \pm 0.1 \\ & \\ 606 \pm 75 & 4.4 \pm 0.1 \\ 422 \pm 25 & 4.7 \pm 0.1 \\ 420 \pm 12 & 3.7 \pm 0.2 \\ 589 \pm 170 & 4.1 \pm 0.3 \\ 678 \pm 36 & 4.3 \pm 0.1 \\ 934 \pm 63 & 4.3 \pm 0.2 \\ 445 \pm 87 & 4.5 \pm 0.0\end{array}$

$169 \pm 40(128-217)$

$151 \pm 99(83-265)$

$1710 \pm 451(1065-2529)$

$1997 \pm 1138(1095$ - 3598)

$1021 \pm 816(524-3147)$

$569 \pm 239(396-1205)$

$2123 \pm 1186(935-4630)$

$2195 \pm 1378(1038-5115)$

$5074 \pm 1403(3426-7473)$

$2188 \pm 419(1797-2678)$

$1718 \pm 1044(344-3960)$

$2329 \pm 1065(1150-3652)$

$3753 \pm 883(2252-4902)$

$502 \pm 232(155-646)$

\section{CRUSTACEANS}

Alpheus glaber

Nephrops norvegicus

Crangon crangon

Munida intermedia

Crangon allmanni

Goneplax rhomboides

Liocarcinus depurator

Polybius holsatus

$\begin{array}{ll}30-119 \mathrm{~m} & 60 \\ 30-119 \mathrm{~m} & 60 \\ 30-119 \mathrm{~m} & 40 \\ 30-119 \mathrm{~m} & 47 \\ 30-119 \mathrm{~m} & 60 \\ 30-119 \mathrm{~m} & 60 \\ 30-119 \mathrm{~m} & 60 \\ 30-119 \mathrm{~m} & 60 \\ & \\ 120-199 \mathrm{~m} & 155\end{array}$

$\begin{array}{cc}43 \pm 1 & 2.6 \pm 0.2 \\ 147 \pm 11 & 2.8 \pm 0.1 \\ 53 \pm 4 & 2.9 \pm 0.2 \\ 58 \pm 12 & 3.0 \pm 0.1 \\ 54 \pm 5 & 3.0 \pm 0.1 \\ 34 \pm 2 & 3.0 \pm 0.1 \\ 48 \pm 2 & 3.0 \pm 0.3 \\ 42 \pm 3 & 3.0 \pm 0.3 \\ 197 \pm 9 & 2.9 \pm 0.2\end{array}$

$150 \pm 41(113-216)$

$624 \pm 71(546-692)$

$202 \pm 133(92-418)$

$202 \pm 65(152-312)$

$210 \pm 25(177-246)$

$256 \pm 33(205-292)$

$480 \pm 239(308-900)$

$540 \pm 309(204-900)$

$2048 \pm 917(736-3663)$ 
Systellaspis debilis

Ephyrina hoskynii

Sergia robusta

Meganyctiphanes norvegica

Gnathophausia ingens
Plesionika heterocarpus

$\begin{array}{ccc}5 & 200-599 \mathrm{~m} & 221 \\ 5 & \geq 600 \mathrm{~m} & 1860 \\ 5 & \geq 600 \mathrm{~m} & 1860 \\ 5 & \geq 600 \mathrm{~m} & 1316 \\ 5 \times 3^{\mathrm{e}} & \geq 600 \mathrm{~m} & 1873 \\ 5 & \geq 600 \mathrm{~m} & 2250\end{array}$

\section{MOLLUSCS}

Cephalopods

Octopus vulgaris

Sepia officinalis

Loligo vulgaris

Eledone cirrhosa

Loligo forbesi

Bathypolypus sponsalis

Octopus salutii

Todarodes sagittatus

Opisthoteuthis agassizii

Teuthowenia megalops

Galiteuthis armata

Histioteuthis reversa

Bivalves

Aequipecten opercularis

Pecten maximus

P. maximus

\section{Gastropods}

Buccinum undatum

Scaphander lignarius

S. lignarius

Buccinum humphreysianum

$\begin{array}{lc}30-119 \mathrm{~m} & 39 \\ 30-119 \mathrm{~m} & 35 \\ 30-119 \mathrm{~m} & 30 \\ 120-199 \mathrm{~m} & 134 \\ 120-199 \mathrm{~m} & 195 \\ 200-599 \mathrm{~m} & 494 \\ 200-599 \mathrm{~m} & 252 \\ 200-599 \mathrm{~m} & 442 \\ & \\ \geq 600 \mathrm{~m} & 1081 \\ \geq 600 \mathrm{~m} & 1939 \\ \geq 600 \mathrm{~m} & 1844 \\ \geq 600 \mathrm{~m} & 2076\end{array}$

$129 \pm 40$

$167 \pm 52$

$179 \pm 56$

$87 \pm 23$

$290 \pm 99$

$67 \pm 6$

$82 \pm 15$

$260 \pm 42$

$310 \pm 73$

$134 \pm 12$

$252 \pm 91$

$54 \pm 22$

$\begin{array}{ccc}<30 \mathrm{~m} & 29 & \mathrm{~b}\left(\mathrm{SF}^{\mathrm{f}}\right) \\ 30-119 \mathrm{~m} & 40 & \mathrm{~b}\left(\mathrm{SF}^{\mathrm{f}}\right) \\ 120-199 \mathrm{~m} & 171 & \mathrm{~b}\left(\mathrm{SF}^{\mathrm{f}}\right)\end{array}$

$61 \pm 1$

$115 \pm 9$

$113 \pm 6$

$\begin{array}{ccc}<30 \mathrm{~m} & 29 & \mathrm{~b}\left(\mathrm{SF}^{\mathrm{f}}\right) \\ 30-119 \mathrm{~m} & 40 & \mathrm{~b}\left(\mathrm{SF}^{\mathrm{f}}\right) \\ 120-199 \mathrm{~m} & 171 & \mathrm{~b}\left(\mathrm{SF}^{\mathrm{f}}\right)\end{array}$

b $\left(\mathrm{SF}^{\mathrm{f}}\right)$

b

b

b

b
$2.9 \pm 0.1$
$2.9 \pm 0.1$
$3.1 \pm 0.2$
$3.4 \pm 0.1$
$3.6 \pm 0.1$
$4.1 \pm 0.1$

$551 \pm 132(444-769)$

$483 \pm 128(328-640)$

$320 \pm 182(127-621)$

$429 \pm 166(236-696)$

$172 \pm 14(160-193)$

$2986 \pm 2599(838-7179)$

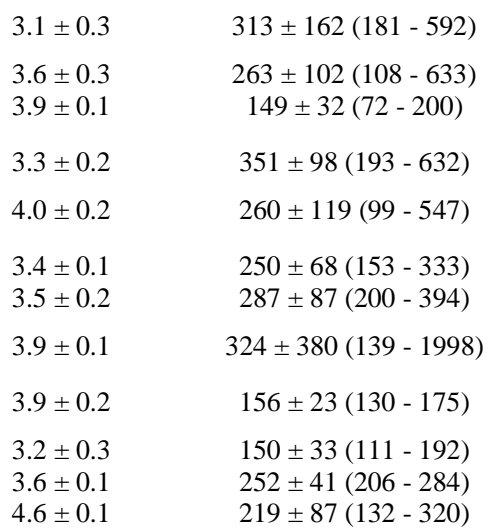

3.7

$2.2 \pm 0.1$
$2.0 \pm 0.2$
$1.9 \pm 0.2$

$39 \pm 9(27-49)$

$44 \pm 13(27-67)$

$103 \pm 11(90-113)$

2.0

$\begin{array}{ll}76 \pm 4 & 2.2 \pm 0.2 \\ 39 \pm 15 & 2.3 \pm 0.1 \\ 42 \pm 6 & 2.2 \pm 0.2 \\ 35 \pm 3 & 3.1 \pm 0.1\end{array}$

$130 \pm 80(59-232)$

$42 \pm 14(31-63)$

$135 \pm 45(63-202)$

$782 \pm 543(442-1723)$

2.4

${ }^{a}$ Corresponds to the categories defined in Materials and Methods (function of the depth under the research vessel at the end of trawling).

${ }^{\mathrm{b}}$ Corresponds to the depth under the research vessel at the end of trawling.

${ }^{\mathrm{c}} \mathrm{b}=$ benthic; $\mathrm{bp}=$ benthopelagic; $\mathrm{p}=$ pelagic.

${ }^{\mathrm{d}}$ Total Length (TL) for most fish, gastropod molluscs and "shrimp type" crustaceans; Dorsal Mantle Length (DML) for most cephalopod molluscs; Standard Width (SW) for bivalve molluscs and "crab type" crustaceans. Exceptions are described below.

- Trachyrincus scabrus, Polymetme thaeocoryla, Bathypterois dubius, Nezumia aequalis, Xenodermichthys copei, Benthosema glaciale, Ceratoscopolus maderensis, Bathylagus greyae, Myctophum punctatum, Arctozenus risso, Argyropelecus olfersii, Lampanyctus crocodilus, Notoscopelus kroeyeri, Stomias boa, Notacanthus bonaparte, Normichthys operosa: Standard Length (SL) instead of Total Length.

- Chimaera monstrosa, Hydrolagus mirabilis and Coryphaenoides rupestris: Pre-Anal Fin Length (PAFL) instead of Total Length.

- Opisthoteuthis agassizii: Total Length (TL) instead of Mantle Length.

- Meganyctiphanes norvegica: Cephalothorax Length (CL) instead of Total Length.

${ }^{\mathrm{e}}$ Trophic Position (see details of calculation in Materials and Methods)

${ }^{\mathrm{f}} \mathrm{SF}=$ suspension feeder 
1 Table 2: Values of some Trophic Enrichment Factors (TEFs) available in the litterature for diferent consumers (i.e., from different taxa), and TEFs finally 2 used to calculate trophic positions (TP) of organisms in this study from stable isotope ratios.

\begin{tabular}{|c|c|c|c|}
\hline Taxa & $\begin{array}{c}\text { TEF from the literature } \\
\text { (examples) }\end{array}$ & Reference & TEF finally used in TP calculation and explanation \\
\hline Actinopterygian fish & $\begin{array}{l}\text { wide range of values in various } \\
\text { species }\end{array}$ & $\begin{array}{l}\text { Vanderklift and Ponsard 2003; } \\
\text { Sweeting et al. 2007; Caut et al. } \\
2009\end{array}$ & $\begin{array}{l}3.2 \text { (as recommended by Sweeting et al. } 2007 \text {, the most } \\
\text { specific study for } \delta^{15} \mathrm{~N} \text { TEF in Actinopterygian fish } \\
\text { muscle) }\end{array}$ \\
\hline Chondrichthyan fish & $\begin{array}{l}2.3 \text { in average in sand tiger } \\
\text { (Carcharias taurus, } \mathrm{n}=3) \text { and } \\
\text { lemon shark (Negaprion } \\
\text { brevirostris, } \mathrm{n}=1)\end{array}$ & $\begin{array}{l}\text { Hussey et al. 2010a (see also } \\
\text { Hussey et al. 2010b, Logan and } \\
\text { Lucatvage 2010) }\end{array}$ & $\begin{array}{l}2.3 \text { (as recommended by Hussey et al. 2010a, the most } \\
\text { specific study for } \delta^{15} \mathrm{~N} \text { TEF in Chondrichthyan fish } \\
\text { muscle) }\end{array}$ \\
\hline Crustaceans & $\begin{array}{l}3.3 \text { in red rock lobster (Jasus } \\
\text { edwardsii, } \mathrm{n}=69 \text { ) } \\
3.6 \text { to } 3.7 \text { in ghost shrimps } \\
\text { (Nihonotrypaea japonica, } \mathrm{n}=14 \text { and } \\
\text { N. harmandii, } \mathrm{n}=13 \text { ) }\end{array}$ & $\begin{array}{l}\text { Suring and Wing } 2009 \\
\text { Yokoyama et al. } 2005\end{array}$ & $\begin{array}{l}3.4 \text { for all invertebrates (as recommended by Post } 2002 \mathrm{a} \\
\text { in general, and due to the general lack of specific data) }\end{array}$ \\
\hline Cephalopod molluscs & $\begin{array}{l}3.3 \text { in common cuttlefish (Sepia } \\
\text { officinalis, } \mathrm{n}=5 \text { ) }\end{array}$ & Hobson and Cherel 2006 & \\
\hline
\end{tabular}


Table 3: Detailed results for the 3 categorical variables included in the GAM model, fitted to average log-transformed $\mathrm{Hg}$ concentrations for each species analysed for metal concentrations in the muscle (120 species).

\begin{tabular}{|c|c|c|c|c|c|}
\hline $\begin{array}{c}\text { GAM categorical } \\
\text { explanatory } \\
\text { variables }\end{array}$ & Categories & $\begin{array}{c}\text { Number } \\
\text { of } \\
\text { species }\end{array}$ & $\begin{array}{c}\text { Trophic } \\
\text { position } \\
(\text { min-max) }\end{array}$ & $\begin{array}{l}\text { Hg concentration in } \\
\text { the muscle }\left(\text { ng.g }^{-1} \mathrm{dwt}\right) \\
(\min -\max )\end{array}$ & p-value \\
\hline \multirow[t]{5}{*}{ Depth layer } & $<30 \mathrm{~m}$ & 8 & $2.2-4.3$ & $39-1001$ & - \\
\hline & $30-119 \mathrm{~m}$ & 41 & $2.0-5.0$ & $42-2725$ & 0.679 \\
\hline & $120-199 \mathrm{~m}$ & 19 & $1.9-4.5$ & $103-3223$ & 0.085 \\
\hline & $200-599 \mathrm{~m}$ & 22 & $2.9-4.7$ & $148-5074$ & 0.013 \\
\hline & $\geq 600 \mathrm{~m}$ & 36 & $2.9-4.6$ & $61-3753$ & 0.023 \\
\hline \multirow[t]{3}{*}{ Water column distribution } & Benthic & 31 & $1.9-5.0$ & $39-2465$ & - \\
\hline & Benthopelagic & 65 & $3.5-4.7$ & $65-5074$ & 0.297 \\
\hline & Pelagic & 30 & $2.9-4.6$ & $59-2986$ & 0.013 \\
\hline \multirow[t]{4}{*}{ Taxa } & Actinopterygians & 78 & $3.3-4.6$ & $59-4769$ & - \\
\hline & Chondrichthyans & 14 & $3.6-5.0$ & $151-5074$ & 0.047 \\
\hline & Crustaceans & 15 & $2.6-4.1$ & $150-2986$ & 0.305 \\
\hline & Molluscs & 19 & $1.9-4.6$ & $39-782$ & 0.058 \\
\hline
\end{tabular}




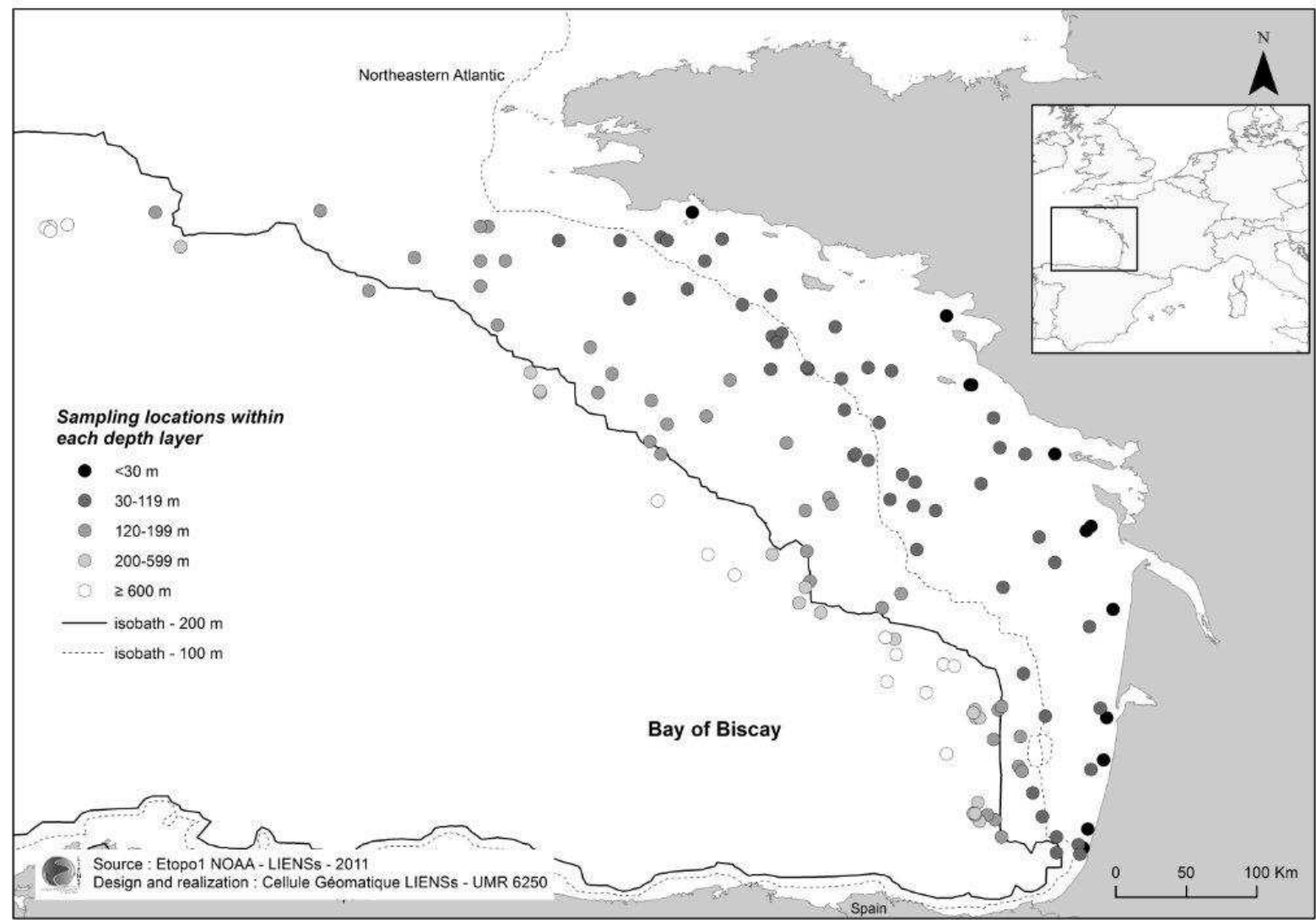

Fig. 1: Map of the study area and sampling locations in Bay of Biscay (North-East Atlantic). The depth layer corresponding to each sampling location is indicated (i.e., depth under the research vessel at the end of species' individuals trawling: < $30 \mathrm{~m} ; 30-119 \mathrm{~m} ; 120-199 \mathrm{~m}$; $200-599 \mathrm{~m} ; \geq 600 \mathrm{~m}$. 


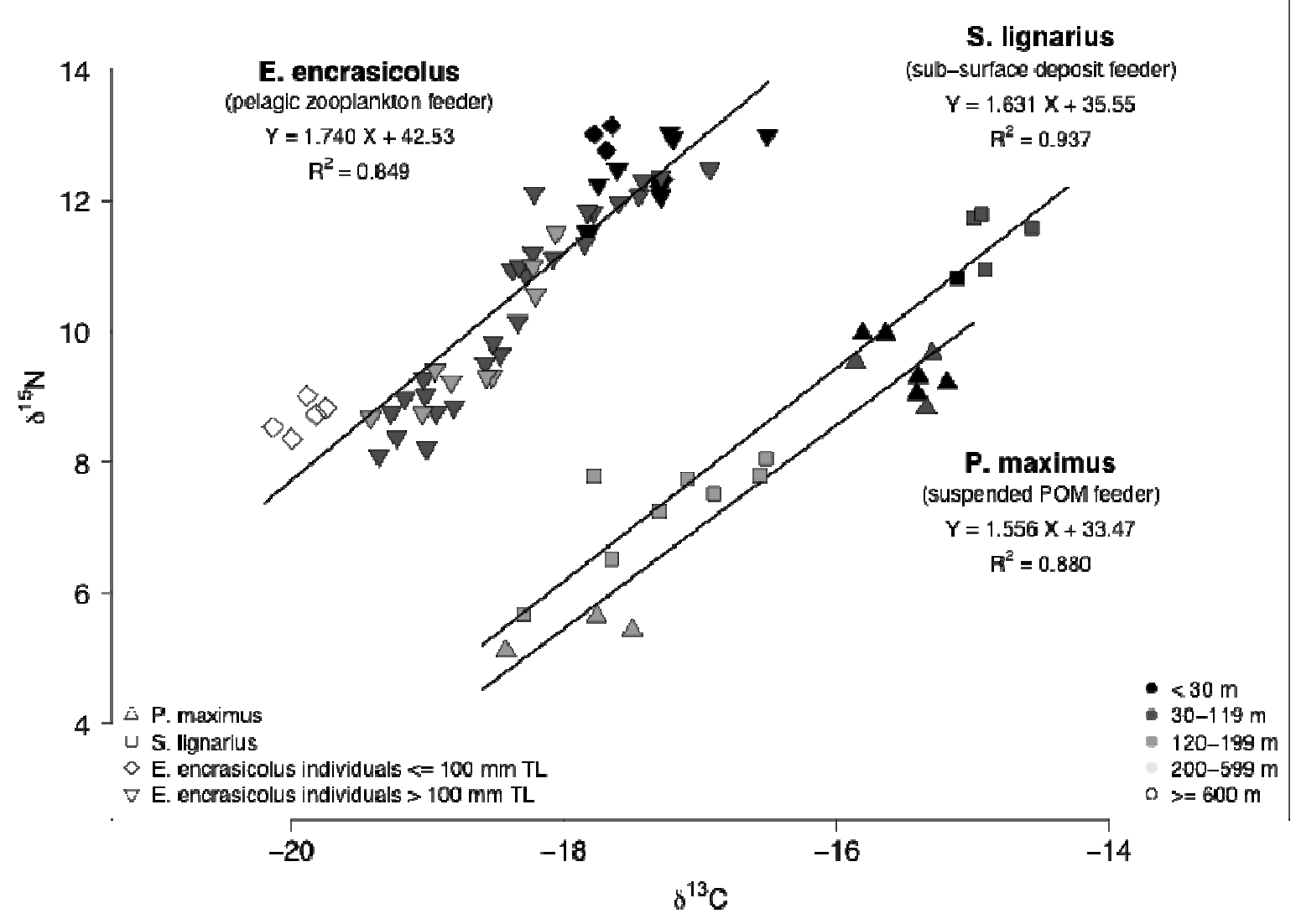

Fig. 2: Investigation of the inshore-offshore gradient of isotopic signatures in the Bay of Biscay, through individuals isotopic signatures within 3 species belonging to 3 different trophic guilds: the great scallop Pecten maximus (a suspended particulate organic matter or Particulate Organic matter - POM- feeder), the see snail Scaphander lignarius (a sub-surface deposit feeder), and the European anchovy Engraulis encrasicolus (a small pelagic fish, zooplankton feeder). Regression parameters and the squared Pearson correlation coefficient $\left(\mathrm{R}^{2}\right)$ are indicated for each species. The different colours correspond to the depth layer organisms were trawled (i.e., depth under the research vessel at the end of trawling). 


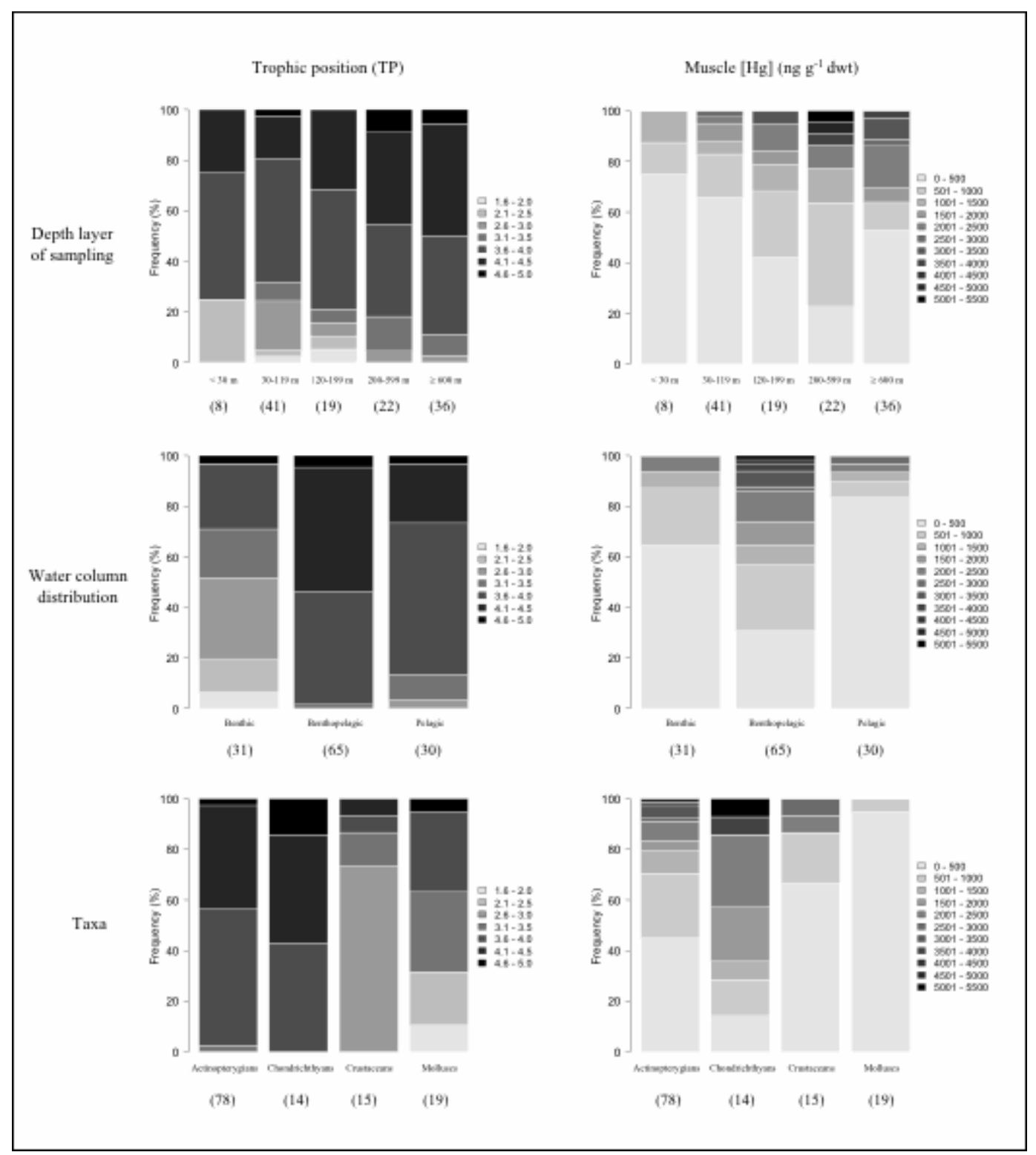

Fig. 3: Frequency (in \%) of the stable isotopes-derived trophic positions (TP), and of the $\mathrm{Hg}$ concentrations measured in the muscle of the different species analysed in the Bay of Biscay. Species are classified following the depth layer of their sampling (i.e., average depth under the research vessel at the end of trawling), their distribution in the water column (i.e., benthic $v s$. benthopelagic vs. pelagic), or the taxa they belong to. Numbers between brackets correspond to the number of species in each category. 

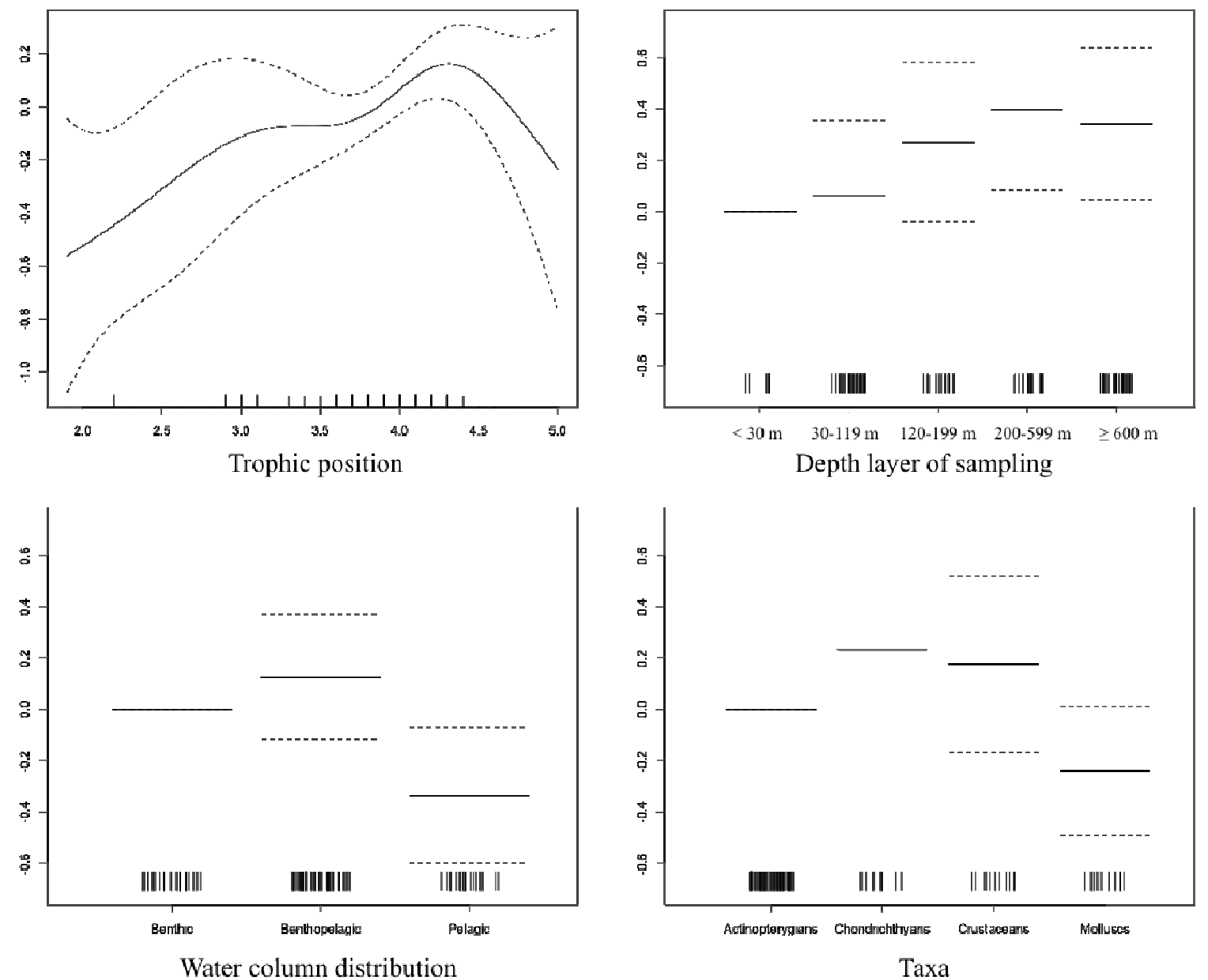

Fig. 4: Graphical results of the GAM model fitted to average log-transformed $\mathrm{Hg}$ concentrations for each species analysed for metal concentrations in the muscle (120 species), to identify trophic position-related, spatial and taxonomic trends in explaining $\mathrm{Hg}$ concentrations variability. For the average trophic position (TP) of species, the smoother illustrates the partial effect of this continuous explanatory variable once the effects of all other explanatory variables or factors included in the model have been taken into account (i.e., effects of the 3 categorical explanatory variables). For these 3 factors (i.e., depth layer of sampling of species, water column distribution of species, and taxa), the model also calculates their effect once the effects of all other explanatory variables have been taken into account. In fact, the effect of each category within a factor is also calculated to a reference category, which corresponds to the first category for each factor. The y-axis shows the contribution of the smoother or of the category to the predictor function in the model (in arbitrary units). Dashed lines represent 95\% confidence intervals. Finally, whiskers on the x-axis indicate data presence. 